\title{
Chagas' Heart Disease
}

\author{
José Antonio Marin-Neto, Marcus Vinícius Simões, Álvaro V. Lima Sarabanda
}

Ribeirão Preto, SP - Brazil

The recovery of $T$. cruzi DNA from South American human mummies shows that Chagas' disease already afflicted mankind as early as 4000 years ago ${ }^{1}$. Charles Darwin probably contracted the disease during his expedition to South America, as suggested by his vivid description of the "benchuca" sting and the nature of his late life symptoms ${ }^{2}$. However, it was in the early twentieth century that Carlos Chagas, in a most unique accomplishment in the History of Medicine, discovered the new morbid entity that carries his name, described its pathological and clinical features, the etiologic agent and its transmission mechanism through the inoculation of infected excreta of hematophagous insects of the family Reduviidae (subfamily Triatominae) ${ }^{3}$.

Although the mechanism by which T. cruzi invades mammalian cells is not completely known, experimental work suggests that an essential step involves triggering of activation of the transforming growth factor (TGF)-beta signaling pathway. Therefore, adherent parasites cannot penetrate cells lacking TGF-beta receptors and replicate within them, whereas administration of TGF-beta potentiates T. cruzi invasion ability in experimental models ${ }^{4}$.

Virtually every organic system may be affected. Megaesophagus and megacolon occur in about $6 \%$ of the chagasic population and neurologic disorders in around $3 \%$, but, by far, Chagas' heart disease is the most serious complication, with clinical manifestations arising in nearly one third of Chagas infected people throughout their life span.

\section{Epidemiological aspects}

Conditions for vectorial transmission range between latitudes $42^{\circ} \mathrm{N}$ and $40^{\circ} \mathrm{S}$ of the American Continent, from Mexico to Argentina. On the basis of limited serological surveys, $4 \%$ to $7 \%$ of more than 200 million Latin Americans are estimated to be chagasic in extensive areas of 21 countries, and 65-90 million are at risk of becoming infected ${ }^{5}$.

Cross-sectional epidemiological studies in Brazil and Venezuela assessed the prevalence of clinical manifes-

Hospital das Clínicas da Faculdade de Medicina de Ribeirão Preto - USP

Mailing address: José Antonio Marin-Neto - Div de Cardiologia, Depto de Clínica

Médica - Hospital das Clínicas, FMRP-USP - Av. Bandeirantes, 3900 - 14048-

900 - Ribeirão Preto, SP - Brazil. tations and mortality due to Chagas' heart disease. However, no clear-cut epidemiological picture of Chagas' heart disease is yet available, due to the lack of appropriately designed large-scale studies to address this serious public health problem in extensive areas of the Latin American subcontinent. In addition, case reporting is not reliable even in areas of high endemicity. Probably because of marked variations in the genetic background, parasite strain, climate, socioeconomic and related hygienic-alimentary conditions, and health care policies, the morbidity and mortality rates ascribed to Chagas' disease are extremely variable even among endemic areas of each country ${ }^{6}$.

Although the true prevalence of Chagas' heart disease is unknown, these rough estimates clearly indicate that Chagas' myocarditis is undoubtedly the most common form of cardiomyopathy in Latin-American countries ${ }^{7}$. Also, due to migratory currents between countries and far-distant regions, Chagas' heart disease is likely to become ubiquitous ${ }^{7}$. A reflection of this tendency is exemplified by the recent growing awareness regarding the occurrence of Chagas' heart disease in the United States. Based on a prevalence of $4.5 \%$ of $T$. cruzi serologically detected infection in 205 Latin American immigrants to the USA, and on estimates of the number of such immigrants, approximately half a million infected people are believed to exist now in that country ${ }^{8}$. Moreover, rural-urban migration from endemic areas in Brazil is believed to have brought to large cities half a million infected people in the last three decades ${ }^{6}$.

Other mechanisms of transmission - Infestation can also, infrequently, occur by congenital and oral routes, breast feeding, laboratory contamination, and organ transplantation. Transfusional transmission of T. cruzi is currently under close scrutiny in most places, since a survey carried out from 1988 to 1990 in 850 counties in of Brazil, revealed that serological screening for Chagas' disease was performed in only two thirds of all blood donors ${ }^{6}$. Also, a review of serological surveys for Chagas' infection among blood donors, conducted over the last decade in several countries, disclosed a seropositivity rate ranging from 10 to $50 \%$ in endemic areas ${ }^{9}$.

Prevention - Chagas' heart disease carries a very high social impact, with over 750 thousand years of productive life probably lost annually, due to premature deaths in LatinAmerican countries, at a cost of about US $\$ 1200$ million/year ${ }^{10}$. 
These are figures that thoroughly substantiate the concept that elimination of Chagas' disease vectorial (by improving the quality of housing and use of residual insecticides) and of transfusional transmission in both endemic and nonendemic areas ${ }^{11-13}$, is a highly cost-effective public health policy ${ }^{7,10}$. Despite being hindered by financial limitations, these goals have been attained in scattered regions ${ }^{14-16}$.

The Southern Cone Initiative program launched in 1991 has already produced impressive results at a cost of US\$ 207 million that was allocated from national resources of the six countries involved ${ }^{5,16,17}$. Thus, in Brazil, the $89 \%$ reduction in the number of house-infested counties was accompanied by a drop in the rate of $T$. cruzi infected blood donors from $6.5 \%$ to $1 \%$, from 1982 to $1993^{16,17}$. On the basis of such figures, interruption of transmission is expected to occur between 1998 and 2000 in Brazil, Argentina, Chile and Uruguay ${ }^{5,18}$. However, it may be too early for such high expectations, as suggested by sporadic reports of transmission of the disease in areas previously consi-dered under epidemiological control ${ }^{19}$.

\section{Natural history and prognostic factors}

Experimental, pathological and clinical evidence substantiate the conceptual division of Chagas' heart disease into the acute myocarditis and the chronic phase, separated by the long period - 10 to 30 years - known as the indeterminate form of the disease, that constitutes its most intriguing conundrum ${ }^{7,20,21}$. Reactivation of Chagas' disease, with proteiform clinical expression, is now often seen in chronic chagasic patients with various causes of immunodeficiency, natural or iatrogenically induced ${ }^{22-25}$.

Several observational studies mainly conducted in endemic areas in Brazil, Argentina and Venezuela, since the early 1940s disclosed the natural history of Chagas' heart disease ${ }^{7,26-43}$.

Also, many case-series studies describe the acute phase of Chagas' disease acquired through nonvectorial transmission, but have limited value for the knowledge of its natural history ${ }^{7,22-26}$.

Natural history studies of Chagas' heart disease derive predominantly from cross-sectional observations of infected people in rural areas of those countries ${ }^{7}$. Very few studies have described case-control populations of chagasic and non-chagasic people. Other observational investigations focused on the description and follow-up of hospital-based cohorts of chagasic patients ${ }^{7,38-41}$.

Both the rural and hospital-based types of studies have clear limitations for the assessment of the influence of prognostic factors in Chagas' heart disease's natural history ${ }^{7}$. Thus, no adequate identification of cardiac involvement is usually provided in most of the rural-based studies ${ }^{27-37}$. Conversely, in hospital-based studies the heart disease is usually well characterized, but their results can not be extended to the whole spectrum of the chagasic population ${ }^{8,38-41}$. Furthermore, because of the rather protracted course of heart involvement, from the acute myocarditis to the end-stage heart failure or malignant arrhythmia, no prospective studies encompassing the whole span of the disease in sizable populations are available 7,42 .

Prognosis in the acute phase - Although cardiac myocarditis is a constant finding in biopsy specimens or at necropsy examination ${ }^{26}$, case series reported in endemic areas using specific serological tests have shown that only around $10 \%$ of the acute cases have clinical manifestations consistent with a correct clinical diagnosis of Chagas' disease ${ }^{27}$. This is a major obstacle for gathering direct insight into the transition from the acute to the chronic stages of human Chagas' disease. Nevertheless, studies in experimental models of Chagas' disease are in general agreement with such findings.

When the clinical diagnosis was possible (in the small subset of patients), cardiac involvement occurred in around $90 \%$ of 313 successive cases; in $70-80 \%$ cardiac enlargement was seen on X-rays, contrasting with only $50 \%$ of cases showing electrocardiogram (ECG) abnormalities. The severity of myocarditis was inversely proportional to age, with signs of heart failure being twice more intense in children aged up to two years than in those between the ages of three and five years ${ }^{27}$. Mortality in the acute phase of the disease, in this study, was $8.3 \%$, a higher figure than the 3-5\% reported in similar studies in other endemic areas in Brazil, Argentina and Uruguay. The ECG was normal in $63.3 \%$ of the nonfatal cases, and in only $14.3 \%$ of those who died in the acute phase of Chagas' disease. Of all deaths, $75 \%$ occurred in children less than three years of age. Heart failure was the constant finding in all fatal cases, associated or not with encephalitis, and independent of age ${ }^{27}$.

Of 172 patients whose acute phase of Chagas' infection had been diagnosed on the basis of general clinical signs and a positive serology, followed in Bambui (central Brazil) for up to 40 years, the development of chronic cardiac involvement - based on clinical signs, ECG and chest $\mathrm{X}$-rays changes - occurred in $33.8 \%, 39.3 \%$ and $58.1 \%$, respectively during follow-up periods of 10-20 years, 21-30 years and 31-40 years ${ }^{27}$. In another review concerning the same endemic area, for 268 patients whose acute phase of the disease had been diagnosed in an average of 27 years before, the overall mortality in the period was $13.8 \%{ }^{27}$.

Survival is characterized by disappearance of symptoms and signs of heart failure within 1-3 months, and normalization of the ECG in over $90 \%$ of the cases after one year of the infection.

However, there is no evidence of spontaneous cure of the infection, as demonstrated by serial xenodiagnosis and serological tests in studies of several hundreds of chagasic patients ${ }^{7}$.

Prognosis in the indeterminate phase - Although the clinical relevance of this definition could be currently disputed, the indeterminate phase of Chagas' disease 
requires that patients have positive serology and/or a positive xenodiagnosis test, no cardiovascular or digestive symptoms, a normal resting 12-lead ECG and no abnormalities detected by radiological examination of heart, esophagus and colon. Thus, the indeterminate phase ends and the chronic cardiac or digestive forms of the disease ensue only when symptoms appear or abnormalities are shown on the ECG or by radiological cardiac or digestive scans.

The evolution potential at this stage of the disease, determined by as yet unknown factors, is shown by longitudinal cohort studies in endemic areas. A 1-3\% per year rate of appearance of heart involvement has been observed in several studies ${ }^{7}$.

Of 400 young adults followed for 10 years, 91 (23\%) showed clinical and/or ECG or chest-X-ray markers of cardiac disease. Of note, eight deaths were recorded in that period, of which only one could be ascribed to recrudescence of chagasic cardiomyopathy ${ }^{30}$.

Another longitudinal study in Bambui, central Brazil, contrasted the evolution of 885 young chagasic patients in the indeterminate phase, for 10 years, with that of 911 chagasic patients with initially abnormal ECG, in the same period. Survival after 10 years was $97.4 \%$ and $61.3 \%$, respectively for the indeterminate group and the group with cardiac involvement ${ }^{31}$.

A third longitudinal study in a rural Venezuelan community, with $47 \%$ prevalence of positive serology for Chagas' disease, followed 364 patients for a mean period of four years. It revealed the appearance of heart disease at a rate of $1.1 \%$ per year in seropositive individuals. Mortality was 3\% in the four years of follow-up and Chagas' heart disease was the cause of death in $69 \%$ of all fatal cases ${ }^{32}$.

In 1973 a longitudinal study was initiated in a rural community in northeast Brazil. In the initial cross-sectional study of 644 individuals aged $>10$ years, $53.7 \%$ were seropositive. The population initially described in 19731974 was re-examined in 1977,1980 and 1983. The overall rate of development of abnormal ECG was $2.57 \%$ in seropositive (248) as compared to $1.25 \%$ per year in seronegative (332) individuals, a relative risk of two for the same geographical area. The age-adjusted mortality rate was higher in seropositive (8.9/1000/year of 488 patients) than in seronegative individuals (7.8/1000/year of 509 individuals). However, mortality in this study was strongly associated with ventricular conduction defects and arrhythmias ${ }^{33}$.

In summary, the results of these studies indicate that, as long as the patients remain in the indeterminate phase, their prognosis is fine ${ }^{7}$. It must be emphasized that these results were obtained in chagasic populations with $>50 \%$ of the individuals younger than 20 years, and less indeterminate cases are found in older age groups because of the evolutive nature of the disease. It is relevant to know that after 10 years almost $80 \%$ of the patients remain in the indeterminate phase of the disease and probably $50 \%$ of the entire population will have no signs of heart disease throughout their lives. What remains elusive are those factors which determine the development of overt cardiac disease and cardiac failure in some patients who have been infected with $T$. cruzi as opposed to others with positive serology but without cardiac involvement ${ }^{7}$. It is likely that the explanation will be multifactorial.

Prognosis of chronic Chagas' heart disease - From the studies mentioned above, analyzing prognostic factors of the indeterminate phase in rural populations in which only a superficial evaluation of the heart condition was carried out, it became apparent that the mere appearance of ECG changes entailed a bad prognosis ${ }^{34,35}$. Also, a retrospective analysis of seropositive individuals followed over 18 years revealed that right bundle branch block was three times more common in fatal cases than in survivors ${ }^{34}$.

In addition to ECG markers, the notion that the male gender is an important deleterious prognostic factor once the heart disease is manifest, is borne out from several studies carried out with long-term follow-up of hospitalbased cohorts of chagasic patients and also by a casecontrol study ${ }^{27-29}$. The later study also suggests possible geographical clustering and/or familial aggregation of cases of Chagas' heart disease in endemic areas ${ }^{29}$.

Few case-control follow-up studies have been reported in endemic areas ${ }^{7,36,37}$. In central Brazil ${ }^{36}$, two crosssectional clinical assessments spanning 10 years (1974 to 1984) were carried out including 12-lead ECG and radiological evaluation of heart size. Serum positive patients and controls were matched by age and gender. In the first crosssectional study, 264 pairs of subjects were evaluated, of which 110 could be recomposed and reexamined after the 10-year follow-up period, with the same clinical, ECG and chest-X-ray assessment. The incidence of clinical heart disease, as diagnosed by the development of symptoms, ECG and/or radiological changes, in previously healthy but serologically positive individuals was $38.3 \%$ in the ten-year period. In those patients with previous heart involvement a rate of $34.5 \%$ of deterioration was observed in the same period. In the chagasic population the overall mortality was $23 \%$, compared with $10.3 \%$ in the controls. Moreover, cardiac mortality, including sudden death and death in heart failure was $17 \%$ among chagasic patients, and only $2.3 \%$ in the control population. Again, the overall mortality was much higher in chagasic males and predominated in the group aged 30 to 59 years $^{36}$.

The same group of investigators, applying similar methods in northeastern Brazil showed that mortality rates were $1.6 \%$ and $0 \%$ for 125 matched pairs of respectively chagasic and nonchagasic patients followed for 4.5 years ${ }^{37}$. Progression of disease as assessed by ECG changes occurred in only $10.4 \%$ of patients, as compared to $4.8 \%$ of controls. The different morbidity and mortality rates between the two regions were hypothesized to mean possible differences in the pathogenicity of $T$. cruzi strains in the two geographical regions, but no direct evidence for this was provided ${ }^{7}$.

There is also evidence to support the notion that 
mortality associated with Chagas' disease is strongly correlated with the severity of the myocardial dysfunction ${ }^{7}$. For example, survival two years after the first episode of heart failure was only $33.4 \%$ in 160 cases $^{38}$. Of note, $10 \%$ of deaths were sudden. In addition 98 deceased people were autopsied, revealing $<20 \%$ of prevalence of cardiac tissular forms of $T$. cruzi, with a clear predominance of this finding in male patients ${ }^{38}$.

In a study of 107 chagasic patients followed for 10 years, a significant reduction in life expectancy, as compared to that of 22 nonchagasic patients, was detected only in those with ECG and/or clinical changes. A mortality rate of $82 \%$ over the 10 -year follow-up period was seen in the group of 34 patients with signs of heart failure at the beginning of the study. In contrast, a $65 \%$ 10-year survival was associated with ECG abnormalities but in absence of signs of heart failure ${ }^{39}$.

Another study of 104 male patients admitted to the hospital with congestive heart failure revealed a mortality rate of $52 \%$ after five years. The strongest predictors of survival were left ventricular (LV) ejection fraction and maximal oxygen uptake during exercise ${ }^{40}$.

In a series of 42 patients with Chagas' heart disease in the USA, 11 deaths occurred during a mean follow-up of nearly five years, always in association with global or regional LV dysfunction. Established or developing heart failure was a strong predictor of mortality, but, quite surprisingly, not aborted sudden death or the presence of sustained ventricular tachycardia ${ }^{8}$. These results conflict with the evidence that ventricular tachycardia detected during exercise testing is a marker of increased risk of sudden death in 44 chagasic patients followed for a mean period of two years ${ }^{41}$. This discrepancy is likely related to the fact that both studies are fraught with the same limitation of small numbers and a relatively short follow-up.

In summary, there is substantial evidence that the most important prognostic factor in established Chagas' heart disease is the degree of myocardial dysfunction. Once overt cardiac failure is manifest, the prognosis is bleak, similarly to that reported in the heart failure Framingham cohorts, with mortality rates approaching $50 \%$ in four years. It is possible - but by no means proven by good evidence - that sudden death and related ventricular arrhythmias may play a more prominent role in mortality due to Chagas' disease than in heart failure due to other etiologies ${ }^{7}$.

\section{Clinical features of Chagas' heart disease}

Following inoculation by the etiologic agent, there is an incubation period of approximately 7 to 10 days. Local skin or mucosa swelling produces the typical entry lesions known as chagomas (including the nonspecific Romaña's sign).

Cardiac abnormalities are always present in all stages of Chagas' disease, but, characteristically, in the acute phase, there is a striking discrepancy between the severity of the myocarditis and the paucity of its clinical expression ${ }^{7}$. Gene- ral infective signs of disease (fever, myalgia, sweating, hepatosplenomegaly) at this stage are usually accompanied by nonspecific laboratory findings: leukocytosis with an absolute increase in lymphocyte count, chest X-rays cardiomegaly and ECG changes (sinus tachycardia, ventricular ectopic beats, low voltage, diffuse ST-T alterations, first degree atrioventricular block). Serologic tests for T. cruzi infection are usually negative during the first weeks, but circulating parasites may be detected by xenodiagnosis. The diagnosis of acute Chagas' disease due to blood transfusion requires a high level of awareness, particularly in nonendemic areas ${ }^{42}$. This notion also applies regarding the problem of recognizing recrudescence of Chagas' disease in immunocompromised patients who have the chronic form ${ }^{42}$.

Necropsy studies and in vivo investigations, using several methods to evaluate the ventricular performance, myocardial perfusion, cardiac autonomic function and rhythm, and findings on RV biopsy - demonstrate that virtually all patients, even in the indeterminate phase of the disease, have at least some subtle degree of cardiac involvement $^{7,43-48}$.

It is important to emphasize that all the anatomical and functional disturbances detected during life are consistent with the autopsy findings reported on several series of chagasic patients who died in the various stages of the disease $^{43,44,49,50}$.

On the basis of the prognostic implications discussed above, it would be convenient to classify patients with Chagas' heart disease according to the presence of symptoms, physical and ECG abnormalities, cardiac enlargement, right and LV systolic and diastolic dysfunction, myocardial perfusion defects, cardiac autonomic impair-ment and RV biopsy findings (table I).

Symptoms and physical signs appearing in patients with the chronic stage of the disease arise from three basic syndromes that may coexist in the same patient: heart failure, cardiac arrhythmia, and systemic and/or pulmonary thromboembolism.

Heart failure of chagasic etiology is usually biventricular. However, the manifestations of right-sided failure (increased jugular venous pressure, peripheral edema, ascites, and liver enlargement) are usually more pronounced than those of left-sided failure (dyspnea and pulmonary rales) ${ }^{51}$. Fatigue is also a common symptom. Physical examination often reveals murmurs of mitral and tricuspid regurgitation, wide splitting of the second heart sound with an accentuated second component (P2), due to the combination of a right bundle branch block and pulmonary hypertension, and a prominent apical thrust.

Cardiac arrhythmias (such as bouts of ventricular tachycardia) cause palpitation, lightheadedness, dizziness, or syncope ${ }^{52}$. The latter symptoms may also be caused by complete heart block, that can be detected by careful examination of the jugular venous pulse and cardiac auscultation. The severity of ventricular arrhythmias tends to correlate with the degree of LV dysfunction. However, it is not uncommon to have patients with ventricular tachy- 


\begin{tabular}{|c|c|c|c|c|}
\hline \multicolumn{5}{|c|}{$\begin{array}{l}\text { Table I - Pathophysiological classification of chronic Chagas' heart disease, according to evolution stage, } \\
\text { based on clinical and laboratory features* }\end{array}$} \\
\hline \multirow{2}{*}{$\begin{array}{l}\text { Clinical Presentation } \\
\text { Evolution Stage }\end{array}$} & \multicolumn{2}{|c|}{ Indeterminate } & \multirow{2}{*}{$\begin{array}{l}\text { Overt heart disease } \\
\text { II }\end{array}$} & \multirow{2}{*}{$\begin{array}{l}\text { Heart failure } \\
\text { III }\end{array}$} \\
\hline & IA & IB & & \\
\hline Symptoms & Absent & Absent & Minimal & Prominent \\
\hline Physical Examination & Normal & Normal & May be abnormal & Abnormal \\
\hline ECG changes & Absent & Absent & RBBB, LAHB, AVB, LBBB, PEVB & $+\mathrm{Q}$ waves $\mathrm{TV}$ \\
\hline Heart size & Normal & Normal & Normal & Enlarged \\
\hline \multicolumn{5}{|l|}{ (X-rays) } \\
\hline RV function & Normal & May be depressed & Commonly Abnormal & Abnormal \\
\hline LV diastólic function & $?$ & Mild abnormalities & Abnormal & Abnormal \\
\hline LV systolic function & Normal & Mild segmental dyssynergia & Segmental dyssynergia & Globally depressed \\
\hline Perfusion defects & $?$ & May be detected & Common & Common \\
\hline Autonomic function & $?$ & May be abnormal & Commonly abnormal & Abnormal \\
\hline RV biopsy & $?$ & May be abnormal & Abnormal & Abnormal \\
\hline \multirow[t]{3}{*}{ Exercise Stress test } & Normal & May be abnormal: & May be abnormal: & Abnormal: \\
\hline & & - arrhythmia & - arrhythmia & reduced \\
\hline & & - chronotropic deficit & - chronotropic deficit & capacity \\
\hline Arrhythmia/Sudden death & Absent & Very uncommon & May be detected & Common \\
\hline
\end{tabular}

cardia or complete AV block who have well preserved global ventricular performance (but usually regional wall motion abnormalities) $)^{52}$.

Sudden unexpected death occurs with an undefined but not negligible frequency and can supervene (albeit rarely) even in patients previously asymptomatic. It is usually precipitated by physical exercise, and associated with ventricular tachycardia and fibrillation or, more rarely, with complete AV block. From autopsy studies, it is apparent that such patients have constant but variable degrees of inflammatory abnormalities and neuronal cardiac depopulation ${ }^{44}$. In addition, necropsy and in vivo studies show that most such patients have ventricular aneurysm at one or more sites (posterior, inferolateral, or apical) ${ }^{42}$.

Systemic and pulmonary embolism, arising from mural thrombi in cardiac chambers and from deep venous thrombosis due to low cardiac output, is a conspicuous complication of chronic Chagas' heart disease. However, evidence from postmortem studies suggests that emboli are often overlooked. In a review of 1345 autopsy cases, the incidence of cardiac thrombus or thromboemboli was 44 percent; the right and left cardiac chambers were equally affected ${ }^{50}$. Although thromboembolic phenomena were more common in the systemic circulation, pulmonary embolism accounted for 14 percent of deaths. Chest pain, more often atypical for myocardial ischemia, is another common symptom ${ }^{8,47,53,54}$. In a small but appreciable subset of chagasic patients, it may mimic an acute coronary syndrome ${ }^{55,56}$.

\section{Diagnostic laboratory methods}

It is remarkable that some chagasic patients with conspicuous ECG and ventricular regional abnormalities may be asymptomatic hard workers ${ }^{7,44,47}$. The appropriate use of several diagnostic methods will detect the cardiovascular dysfunction in virtually all patients, and help in establishing both the diagnosis and prognosis ${ }^{42}$.

Serologic tests - The etiologic diagnosis is routinely performed with methods that detect circulating antibodies that bind to parasite antigens ${ }^{57}$. The most commonly used tests are based upon complement fixation, immunofluorescence, or ELISA assays, that, carefully standardized, achieve sensitivity and specificity rates higher than 90 percent. Chagas' disease is diagnosed with greater sensitivity by the detection of $T$. cruzi specific sequences of DNA, using molecular biology approaches ${ }^{58-60}$. These later techniques also have the potential for improving the diagnostic and prognostic characterization of the disease, on the basis of parasite strain identification ${ }^{60}$.

Electrocardiogram - The most common alterations on the routine ECG are right bundle branch block, often associated with left anterior hemiblock, diffuse ST-T changes, ventricular premature beats that may be multiform, and runs of nonsustained ventricular tachycardia. Other frequent findings are abnormal Q waves and various degrees of atrioventricular block and, in more advanced stages of disease, atrial fibrillation and low QRS voltage ${ }^{61}$.

Chest x-ray - The most common radiographic finding is marked cardiomegaly with mild or absent pulmonary congestion ${ }^{42}$.

Ambulatory electrocardiographic monitoring Virtually all types of atrial and ventricular arrhythmias can occur including sinus node dysfunction, intermittent com- 
plete atrioventricular block, and complex ventricular arrhythmias ${ }^{52,62}$.

Echocardiography - In the early stages, echocardiography may reveal one or more areas of dyssynergia, including the typical, almost pathognomonic ventricular aneurysm. More advanced disease is revealed by global ventricular dilatation and diffuse hypokinesis, often associated with mitral and tricuspid regurgitation ${ }^{63}$.

Exercise testing - Exercise testing is of limited usefulness for the evaluation of patients presenting with chest pain because, as noted above, most have baseline electrocardiographic abnormalities ${ }^{64}$. However, this test may constitute an alternative to ambulatory monitoring for the detection of exercise-related ventricular dysrhythmia ${ }^{41,65}$. A deficient chronotropic response can also be detected in chagasic patients, due to parasympathetic denervation of the sinus node ${ }^{66,67}$.

Radionuclide angiography - Although less frequently used than echocardiography for clinical purposes, radionuclide angiography has been employed in inves-tigations aiming at the detection of early impairment of biventricular function. Regional wall motion abnormalities and global right ventricular dysfunction may be detected in patients with the indeterminate or isolated digestive form of the disease in whom LV performance is still preserved ${ }^{68,69}$.

Myocardium perfusion scintigraphy - Both transient (reversible or paradox) and irreversible perfusion defects are usually detected by myocardial perfusion scanning of patients who complain of angina-like pain. Perfusion disturbances occur in the presence of normal epicardial coronary arteries and probably represent abnormalities of the coronary microvasculature or areas of myocardial fibrosis $8,47,53$.

Cardiac catheterization and angiography - Cardiac catheterization and angiography may be mandatory in patients with symptoms but elusive electrocardiographic or scintigraphic signs of ischemia, to confirm or, more frequently, to exclude the presence of epicardial obstructive coronary artery disease ${ }^{42,53-56}$. The method also depicts the regional wall motion abnormalities that may be accompanied by mural thrombosis ${ }^{54}$.

Electrophysiologic testing - This test is indicated in selected cases to assess sinus node function and atrioventricular conduction when the origin of symptoms remains uncertain after noninvasive evaluation ${ }^{42}$. Although definitive evidence of benefit is lacking, this procedure is also useful in two other subsets: survivors of sudden cardiac death; and those with sustained ventricular tachycardia to determine prognosis and to select the appropriate antiarrhythmic therapy (medical, surgical, or implantable device) ${ }^{70,71}$.
Electrophysiologic testing does not have an important prognostic role in most patients with preserved LV function who have nonsustained ventricular tachycardia or in those without spontaneous arrhythmia. Programmed stimulation did not induce sustained ventricular tachycardia in any of 72 patients with 400 to 1200 ventricular extrasystoles/hour, of whom 35 percent had nonsustained ventricular tachycardia on Holter monitoring ${ }^{71}$. The mean LV ejection fraction in this group was 60 percent. During an average follow-up of 36 months only 1 of the 72 patients had spontaneous sustained ventricular tachycardia ${ }^{71}$.

Signal averaged electrocardiogram - Preliminary experience in patients not showing conduction distur-bances suggests that late potentials occur more frequently with sustained ventricular tachycardia than in its absence but the significance of this finding remains to be determined ${ }^{72}$. The presence of late potentials also seems to correlate with the degree of myocardial depression ${ }^{73}$.

Magnetic resonance imaging - Although not yet used for clinical purposes, this method has the potential to show the underlying myocarditis and also may provide accurate anatomic and functional characterization of cardiac involvement ${ }^{74}$

Cardiac autonomic assessment - Cardiac autonomic dysfunction, mainly parasympathetic, can be shown in chagasic patients (including those with isolated digestive disease) whose heart response to several autonomic tests (including the RR variability measurement) is impaired, as compared to control subjects ${ }^{47,75,76,77}$. However, these abnormalities are neither correlated with any symptoms, nor cause postural hypotension.

\section{Pathological abnormalities}

Necropsy findings in humans have been correlated with observations in several animal models of experimental Chagas' disease reproducing the various stages of the disease ${ }^{43,78-86}$. Endomyocardial biopsy has also been used in subsets of the chagasic population, including patients in the indeterminate phase ${ }^{46,87}$.

The main cardiac pathologic changes during the acute phase consist of four-chamber marked dilation and pericardial effusion.

Microscopic examination shows intense parasitism in virtually every organic system. The myocarditis is intense and diffuse, showing myocyte necrosis, interstitial edema, vasculitis, and mononuclear and polymorphonuclear infiltration. The inflammatory process may reach the endocardium, resulting in thrombus formation. The conduction system is also involved, as well as the intramural and extracardiac neuronal ganglia.

In chronic patients who die after the clinical onset of heart failure there is dilatation and increase of cardiac weight (usually 350 to $800 \mathrm{~g}$ ). Dilation is usually more conspicuous 
in the right chambers ${ }^{84}$, and signs of systemic congestion (ascites, hepatomegaly) predominate over lung congestion ${ }^{51}$. It is possible that this peculiar feature of Chagas' heart disease could be explained by early severe damage of the right ventricle, a chamber frequently neglected in many investigations that included cardiac functional evaluation ${ }^{68,69}$.

Intracardiac mural thrombosis in various stages of organization is found in nearly $50 \%$ of such cases; the right and left heart chambers are equally affected ${ }^{50}$. The most specific cardiac anatomic lesion is the ventricular apical aneurysm which, in one series, was noted in 52 percent of 1078 autopsied chagasic patients ${ }^{88}$. The lesion does not show the fibrosis usually seen in aneurysms due to myocardial infarction, and rarely undergoes rupture ${ }^{78,88}$. There is no relation between the frequency of apical aneurysm and age or heart weight, and aneurysms have been reported even in patients who died suddenly, with no apparent previous clinical manifestations of disease ${ }^{44}$. Histologic examination reveals mild chronic myocarditis, manifested by scattered mononuclear cell infiltrates with the surrounding myocytes undergoing various stages of degeneration and necrosis ${ }^{82,89}$. These changes have been traditionally interpreted as not being related to direct parasitism of myocardial cells, since intact parasites are rarely detected in humans and in experimental models of Chagas' disease ${ }^{82}$.

Focal and diffuse fibrosis is prominent, in the myocardium and the conduction system ${ }^{90}$. Preferential involvement of the right bundle branch and the left anterior fascicle of the left bundle by inflammatory and fibrotic changes correlates with the frequent occurrence of ECG block of these structure ${ }^{89}$. Microvascular changes in experimental models consist of decapillarization, interstitial edema, intravascular platelet aggregation and thickening of the vascular basement membrane.

Similar findings are found on endomyocardial biopsy. Studies in patients with the indeterminate form have described changes in approximately 60 percent of patients, although the findings are less severe than those in patients with overt cardiac disease ${ }^{46,87}$.

Striking autonomic neuronal depopulation and nerve degeneration, mostly in the cardiac, esophageal and colon tissues, is another typical feature of chronic Chagas' disease ${ }^{82,91,92}$. However, no correlation exists between the intensity of neuronal destruction and dilation of the organ or other microscopic indices of myocarditis in the chronic phase ${ }^{91}$.

\section{Pathophysiology and pathogenetic mechanisms}

The clinical manifestations and organ damage occurring during the acute phase are clearly linked to parasite presence in target organs like the gastrointestinal tract, central nervous system and heart. High grade parasitemia also correlates with lymphadenopathy, liver and spleen enlargement, as markers of widespread immunologic reaction. As the parasitemia abates, and the systemic inflammatory reaction subsides, it is believed that a silent relentless focal myocarditis ensues, during the indeterminate phase ${ }^{7,78}$. This causes cumulative destruction of cardiac fibers and marked reparative fibrosis. During this phase ventricular arrhythmias and sudden death may rarely occur as manifestations of the underlying focal inflammatory process ${ }^{44,93}$. This is also eventually responsible for myocardial mass loss attaining critical degrees, thereby leading to cardiac dilation and setting the anatomic substrate for malignant ventricular dysrhythmia ${ }^{7,78}$. The support for this basic conceptual framework comes from several investigations in various experimental models of Chagas' heart disease using various animal species. Additional evidence has been provided by many studies correlating clinical and pathological findings in autopsied humans dying in all phases of the disease. All studies were observational and usually included case-series of dozens chagasic patients for the acute and indeterminate phases, and ranging from hundreds to thousands cases for the chronic phase of Chagas' heart disease ${ }^{7,78}$.

Complex ventricular arrhythmia constitutes one of the most important pathophysiological aspects, considering its implication on sudden death. It is believed that complex ventricular arrhythmia is more common in chagasic patients than in other dilated cardiomyopathies, but no adequate comparative study has been reported to support this general belief. As expected, there is reasonable evidence that more complex and frequent ventricular dysrhythmia parallels the worsening of ventricular function ${ }^{94}$. However, complex arrhythmias including nonsustained and sustained VT may also occur in chagasic patients with preserved global $L V$ function. There is growing evidence that the electrophysiological substrate underlying sustained ventricular tachycardia in Chagas' heart disease is a macroreentrant circuit within akinetic or dyskinetic areas in the posterobasal and/or posterolateral regions of the $\mathrm{LV}^{95}$.

Despite recent advances in the understanding of Chagas' heart disease pathophysiology, the main challenge still consists of the identification of the pathogenetic mechanisms acting during the indeterminate phase. The widely disparate clinical and pathological manifestations of the acute and chronic phases of a disease with a common infective basis also needs elucidation.

Basically, four main classes of mechanisms have been implied in the pathogenesis of chronic Chagas' heart disease.

Neurogenic mechanisms - Necropsy studies in humans clearly demonstrated intense cardiac neuronal depopulation in the various Chagas' disease stages ${ }^{49,79-82}$. These findings were reproduced by investigations in animal models of the disease ${ }^{49,83-86,96-99}$. The histopathologic features are foci of damaged nervous tissue arranged in a diffuse and irregular distribution. Neuronal parasitism, periganglionitis and degenerative abnormalities in Schwann cells and nervous fibers have also been observed. Not only cardiac parasympathetic nervous structures are involved but paravertebral sympathetic ganglia destruction has also been described ${ }^{81}$.

Correspondent striking abnormalities of parasym- 
pathetic and, to a lesser extent, of sympathetic cardiac autonomic control have been clearly documented by extensive laboratory investigation in humans ${ }^{47,69,75-77,96}$. This aspect seems to be a hallmark of this disease. In fact, less severe degrees of denervation have been found in rheumatic disease, endomiocardiofibrosis, and idiopathic dilated cardiomyopathy by direct comparative studies with Chagas' disease ${ }^{49}$.

Taking into account the early, intense, and largely predominant parasympathetic denervation in Chagas' disease, that mostly explains the pathogenesis of chagasic megaesophagus and megacolon ${ }^{100}$, a neurogenic theory of Chagas' heart disease has been proposed: a long lasting autonomic imbalance would lead to a catecholamineinduced cardiomyopathy ${ }^{49,79}$.

However, various lines of evidence cast doubts on the participation of neurogenic derangements as main pathogenetic mechanisms of Chagas' heart disease ${ }^{7}$. Thus, the frequency and the intensity of this abnormality are quite variable, and a mismatch between the presence of autonomic denervation and ventricular dysfunction is often seen ${ }^{77,92,96,101-103}$. Differences in $T$. cruzi strain and/or regional environment are likely causes for variable neurotropism observed in several regions ${ }^{99}$. More important, studies aimed at investigating the presence of autonomic dysfunction and early contractile abnormalities have failed to show any significant association ${ }^{69}$.

However, a critical appraisal of this issue should consider that all the investigators mentioned above performed evaluation of autonomic cardiac function integrity by assessment of heart rate control. Hence, evidence of early nervous damage possibly occurring at the ventricular myocardial level, may have been overlooked ${ }^{47}$.

A more appropriate insight into this aspect was obtained by recent investigations using ${ }^{123} \mathrm{I}$-MIBG scintigraphy for evaluation of myocardial sympathetic nerve terminals ${ }^{104-106}$. Segmental areas of sympathetic denervation were detected in a high proportion of patients even in the indeterminate phase of Chagas' heart disease. This is the first functional evidence of cardiac sympathetic impairment preceding left wall motion abnormalities in the indeterminate phase of chronic Chagas' disease.

Increased ${ }^{123}$ I-MIBG washout rate was also observed in patients with normal segmental ventricular function ${ }^{106}$. This could be due to early increased cardiac sympathetic activity, and lend support to the neurogenic theory as stated above. Alternatively, this abnormality could be caused by competition between the radiotracer and an endogenous substance for the neurotransmitter receptors of the sympathetic nerve terminals.

In plausible concordance with this last hypothesis, recent reports have documented in patients with Chagas' disease the existence of circulating antibodies that bind to adrenergic and cholinergic receptors of lymphocytes and myocardium ${ }^{107-111}$. Studies focusing on antibodies against heart adrenergic and cholinergic receptors have shown their ability to trigger physiologic, morphologic, enzymatic and molecular alterations, potentially leading to cardiac damage ${ }^{109-111}$. Deposit of autoantibodies upon the myocardial neurotransmitter receptor could induce its desensitization or down-regulation and cause progressive denervation. Such mechanisms could represent the elusive but significant link between denervation and autoimmune aggression as pathogenetic factors in Chagas' heart disease.

In conclusion, the neurogenic theory is still under debate. Its prognostic meaning has never been assessed, and the hypothesis implicating autonomic impairment in triggering sudden death remains entirely speculative ${ }^{93,112}$.

Parasite-dependent inflammation - For decades no significant pathogenetic role was attributed to $T$. cruzi infection in the chronic phase of the disease, on the basis of histopathological evidence of low-grade fiber parasitism and an intriguing lack of topographic correlation between inflammatory foci and amastigote $T$. cruzi nests ${ }^{82}$. This classical view emphasized the presence of focal lymphocytic myocarditis and myocytolytic necrosis in areas where no parasite could be seen ${ }^{113}$, and seemed to be supported by the finding of very low grade parasitemia that could be detected in only a minority of chronic Chagas' disease patients ${ }^{51,114}$.

However, more recent studies employing immunehistochemical techniques and monoclonal antibodies against T. cruzi antigens have been performed on endo-myocardial biopsy specimens retrieved from chronic Chagas' heart patients and a relationship between parasite antigens and inflammatory foci was observed ${ }^{113,115}$. Similar results were obtained by detection of $T$. cruzi genomic fragments applying the polymerase chain reaction method ${ }^{116}$. In addition, molecular biology techniques now permit the detection of circulating $T$. cruzi antigens in a much larger contingent of chagasic patients in whom the conventional serologic methods fail for such purpose ${ }^{117,118}$. It is plausible to speculate that even low-grade persistent parasitism may lead to a continuous antigenic feedback loop to the autoimmune system, which may constitute the main damaging mechanism in the late phase ${ }^{119-121}$.

A direct role of parasitism in the pathogenesis of chronic Chagas' heart disease can have relevant thera-peutic implications. There is only very incipient evidence regarding the possible favorable impact of etiological treatment in the clinical outcome in the chronic phase of disease ${ }^{122}$. In particular, some results have been reported on a nonrandomized, open label, placebo controlled trials of benznidazole in the clinical outcome of 131 treated and 70 nontreated chronic chagasic patients followed for eight years on average ${ }^{123}$. Significant reduction in the rate of new electrocardiographic abnormalities and in the incidence of clinical deterioration was observed in the treated group. Similar results were also recently obtained employing itraconazole and allopurinol ${ }^{124}$. These results, if confirmed in larger adequately designed studies, would give further support to the theory of direct parasite participation in the establishment and further progression of chronic myo-cardial damage. 
Microvascular disturbances - Various classes of evidence arising from clinical and experimental grounds suggest that transitory ischemic microvascular abnormalities occur in Chagas' heart disease.

The first order of evidence is related to morphological features of chronic myocarditis. The focal distribution of myocytolysis and interstitial reparative fibrosis (features also observed in nonchagasic experimental models of ischemia/reperfusion) is compatible with transient ischemic involvement at the microcirculatory level of discrete groups of fibers ${ }^{125-127}$. Also, pathological involvement of coronary vessels has been shown by necropsy studies ${ }^{127-129}$ and is reinforced by observations in murine experimental models of chronic Chagas' disease ${ }^{130-134}$. In the experimental setting the detection of occlusive platelet thrombi in small epicardial and intramural coronary arteries indicates the occurrence of microcirculatory disturbances likely to produce ischemia detected by special histochemical techniques ${ }^{133,134}$. Moreover, the administration of verapamil (a calcium blocker with prominent vasodilator and antiplatelet effects) to $T$. cruzi infected-mice was accom-panied by significant reduction in mortality and extension of tissue damage ${ }^{135}$.

On clinical grounds, myocardial perfusion abnormalities have been documented by several independent reports using various types of myocardial perfusion markers (thallium-201, ${ }^{99 \mathrm{~m}} \mathrm{Tc}$-Sestamibi, ${ }^{99 \mathrm{~m}} \mathrm{Tc}$-microspheres), during effort and at rest, in chagasic patients with angiographically normal coronary arteries ${ }^{8,47,70,136-142}$. Reversible, fixed and paradoxical perfusion defects, in areas with normal contraction, were found in a large proportion of patients even in the absence of other signs of myocardial involvement.

Abnormal response of coronary flow to acetylcholine administration has been reported in chronic Chagas' heart disease patients, suggesting the occurrence of endothelial dysfunction ${ }^{143}$. The demonstration of abnormal subepicardial coronary artery reactivity to hyperventilation and nitrate administration also supports the notion that functional abnormalities in myocardial flow regulation occur in chagasic patients ${ }^{144}$.

Recent ultrastructural studies in canine experimental models suggest that small vessel involvement may be secondary to direct interaction of inflammatory cells and the endothelium ${ }^{145}$. It is possible to speculate that substances like thromboxane A2, cytokines, and prostaglandins, produced in the inflammatory infiltrate, may have important effects on vascular reactivity. According to this hypothesis, microvascular ischemia documented in Chagas' cardio-myopathy may be secondary to the inflammatory response ${ }^{126}$. Conversely, the ischemic phenomena may represent a feedback loop that potentiates the primary damage mechanism.

It is also reasonable to assume that elucidation of the actual cause of ischemia in Chagas' disease might improve the understanding of the precordial chest pain commonly experienced by the patients and help to establish therapeutic strategies for treatment of this symptom.
Immune mediated cardiac damage - A wide array of scientific investigations is considered to lend support to the theory of autoimmunity as the key process in the pathogenesis of chronic Chagas' heart disease. The concept that the effector cells in the mononuclear chagasic myocarditis may damage nonparasited myocardial fibers has been suggested by histopathologic studies using light microscopy; it was recently corroborated by ultrastructural studies in animal models ${ }^{145}$, and is based on the postulate of abnormal immune cross-reactivity between $T$. cruzi and myocardial antigens.

Antigenic mimicry shared by the T. cruzi and the myocardium has been shown for a series of cross-reactive antibodies directed against several host antigens ${ }^{146-150}$. However, the demonstration that this biological effect could have a clinical counterpart to support the autoimmune nature of this disease required the identification of an organ-specific autoantigen whose injection into the susceptible host could reproduce the lesion. Also, the myocardial damage in such circumstances, should be induced by passive transference of lymphocytes ${ }^{151}$.

This kind of definite support of the lesion mechanism ascribed to the cellular immune infiltrate has been recently obtained by identification of myosin-specific TCD4+lymphocytes in the chronic murine Chagas' disease model ${ }^{152}$. Other evidence was obtained by abrogation of the myocardial damage subsequently to depletion of TCD4+ in chronic infected mice ${ }^{153}$. In addition, myocardial damage could be reproduced in noninfected animals by passive transfer of TDC4+ lymphocytes, obtained from infected mice ${ }^{153}$.

Moreover, specific epitopes associated with the host immune response and potentially able to produce myocardial damage have been recently identified ${ }^{120,154-162}$. There is also evidence that persistent $T$. cruzi antigen presentation to macrophages could lead to cytokyne production, thus modulating the immune response and possibly causing the relative immunosuppressive state responsible for perpetuation of infection ${ }^{121,163,164}$. All these findings can be combined to support the theory of chronic chagasic focal fibrotic lymphocytic myocarditis being determined by autoimmune response to epitopes within myocardial proteins. This break of immune tolerance would be due to mimicry of myocardial antigens by $T$. cruzi, thus inducing cross-reactive immune responses.

In essence, $T$. cruzi inflammatory and autoimmune aggression seem to constitute the more prominent pathogenetic mechanisms. Autonomic disturbances and microvascular ischemia appear to play an ancillary role, acting as amplification loops and contributing to expand myocardial tissue damage. A unified overall pathogenetic framework may be constructed on the basis of such notions (fig. 1).

\section{Management of Chagas' heart disease}

Etiologic treatment - Nifurtimox and benznidazol have been shown to have comparable antitrypanosoma efficacy and also similarly high incidence of untoward side effects, 
commonly responsible for discontinuation of treatment: dermatitis, polyneuritis, leukopenia, gas-trointestinal intolerance ${ }^{165,166}$. A recent report on higher incidence of cancer following antitrypanosoma therapy in heart transplanted patients is also an indication that the search for more effective and better tolerated drugs seems clearly warranted ${ }^{167}$. Recent reports of allopurinol and itraconazole for treating Chagas' disease reactivation after heart transplantation and chronic chagasic yielded intriguing results that require further serious scrutiny before any firm conclusions can be derived ${ }^{124,168}$.

In the acute phase of Chagas' infection, irrespective of the mechanism of transmission (vectorial, blood transfusion, laboratory accident, oral, or even reactivation of chronic disease during immunosuppressive conditions), it is virtually consensual that etiologic treatment is mandatory to control symptoms and life threatening conditions, such as myocarditis and encephalitis, and, presumably, to prevent chronic organ damage. However, the efficacy of treatment regarding this later aspect has not been proved as no controlled long-term follow-up trials have been reported. Parasitologic evaluation shows negativity of xenodiagnosis in over $90 \%$ of cases and serologic tests are negative in $80 \%$, after adequate treatment. The prognostic meaning of conversion to a negative serology has not been established, again due to lack of appropriately designed follow-up studies focusing on this relevant aspect.
Evidence for potential benefits of specific antitrypanosoma chemotherapy in chronic Chagas' heart disease is lacking because misleading criteria have been used to assess therapeutic efficacy and also due to the fact that only small, nonrandomized, noncontrolled trials have been carried out ${ }^{169-171}$. Thus, conversion from a serum-positive to a serum-negative state following therapy is an unreliable marker of the impact of such treatment upon the course of Chagas' disease, because in any event, negative serology is common in the chronic phase. Moreover, large fluctuations of parasitemia occur over time. Another negative aspect in those trials is the bias induced by selection of patients with persistent parasitemia in the pretreatment period $^{7}$. Furthermore, results of experimental studies have shown that in the chronic phase the parasitemia is low or not detectable at all while there is a predominant tissular parasitism by amastigote forms of T. cruzi ${ }^{114}$.

Conversely, persistently positive serologic tests may merely reflect mechanisms of immunological memory, or be associated with cross-reactivity to altered host antigens. Hence, results of any of the serological criteria used to assess the therapeutic value of etiologic treatment in patients with the chronic form of Chagas' heart disease are clearly unreliable. The reported rate of negativity of serological tests following treatment in the chronic phase is consistently very low (4-8\%) in the trials suffering the epidemiological restrictions already pointed out ${ }^{169-171}$.

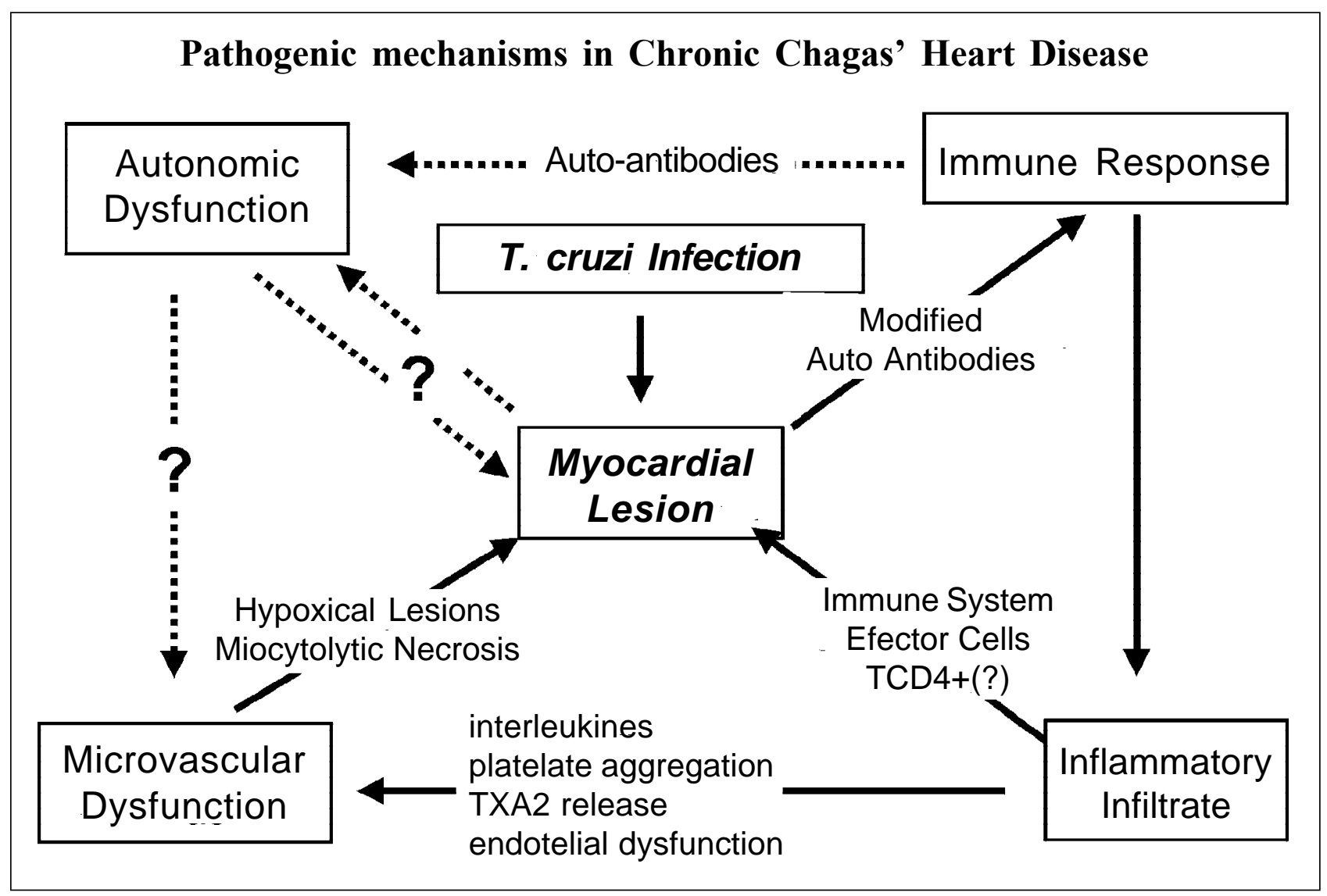

Fig. 1 - Pathogenetic mechanisms in Chagas' heart disease. 
Thus, until an adequate laboratory method is available for assessment of cure, the only acceptable criteria for any etiologic therapeutic intervention benefit must be based on the prevention of the appearance of the clinical form of disease or the arrest of progression of the damage already detected. For this, a very long follow-up period of large cohorts of chagasic patients is required to detect changes in the natural history of the disease.

No definitive recommendations are justifiable for etiologic treatment in the chronic phase of Chagas' heart disease, until large randomized controlled studies encompassing patients in different stages of disease have been performed ${ }^{7}$.

Treatment of congestive heart failure - Since the hemodynamic derangements in chronic chagasic patients with heart failure are comparable to those reported in dilated cardiomyopathies of other etiologies, classical therapeutic interventions (sodium restriction, diuretics, digitalis, and vasodilation with nitrates and hydralazine) are usually employed for relief of congestive symptoms in chagasic patients ${ }^{7}$. Several noncontrolled small studies documented short-term hemodynamic beneficial effects of these agents, and, to a lesser extent, improvement in exercise tolerance in chronic chagasic patients. However, no studies reported improvement in survival, or even in long-term outcome based on hemodynamic and symptomatic benefit ${ }^{7}$.

Preliminary studies involving therapy with ACEinhibitors, enrolling small numbers of patients, have shown promising results in heart failure complicating Chagas' disease ${ }^{172,173}$, in regard to symptomatic control. Although no long-term prospectively controlled study has been reported assessing the impact on survival of chagasic patients treated with ACE-inhibitors or any other pharmacological interventions, there is no reason to expect that their beneficial effect would be any different from that observed in heart failure due to other etiologies. In fact, there seems to be a favorable acute neuromodulating effect of ACE-inhibition in chagasic patients ${ }^{174}$.

As discussed earlier, early regional ventricular wall motion impairment and diminished contractile properties can be seen even in patients with the indeterminate form of the disease ${ }^{63,175}$. Moreover, the mild dyssynergia thus detected appears to reflect more extensive myocardial damage than the ECG changes classically interpreted as heralding more advanced cardiac involvement ${ }^{176}$. Furthermore, there is recent preliminary evidence that these minor segmental wall motion abnormalities in chagasic patients may bear relevant prognostic implications ${ }^{177}$. Therefore, it is reasonable to conclude that it remains to be tested if chagasic patients, similar to what has been shown in other causes of heart failure, would benefit from early medical intervention, to detain the natural history and prevent the installation of overt cardiac dysfunction.

Surgical approaches to treatment - Heart transplantation - As in other cardiomyopathies, heart transplan- tation has been performed in small groups of patients with refractory heart failure due to Chagas' disease. However, wider application of this therapy is currently hindered by socioeconomical factors in endemic areas, and by the reactivation of infective manifestations associated with immunosuppression. Acute myocarditis, with marked transitory LV systolic depression occurred in five of the first nine patients included in the largest series - 22 patients operated in a single surgical center ${ }^{178}$. Although the acute reactivation was usually responsive to antiparasite therapy, the possibility of chronic damage to the allograft could not be ruled out. The results reported on the latest 13 patients of this series, using a reduced regimen of immunosuppression with cyclosporine, are promising as reactivation of disease supervened in only one patient. Also, a survival rate at 24 months posttransplantation of $80 \%$ in that later group, appears to compare favorably with those reported in clinical series. Nevertheless, the long-term impact of heart transplantation in chagasic patients remains to be determined by adequately controlled studies in large cohorts ${ }^{7}$.

Dynamic cardiomyoplasty - Reported experience with this palliative surgical procedure in chagasic patients is quite limited. Initial results showed encouraging symptom and LV function improvement in very few patients ${ }^{179}$. A recent survey of surgical centers in South America showed results pertaining to a total of 112 patients of whom 96 had heart failure due to dilated cardiomyopathy and 13 due to Chagas' heart disease ${ }^{180}$. Comparative analysis disclosed survival rates of $86.1 \%$ and $49.8 \%$ for patients with dilated cardiomyopathy and $40 \%$ and $9.5 \%$ for chagasic patients, at one and five years follow-up, respectively. No clues from these data would point to any factors possibly involved in the worse prognosis thus suggested for chagasic patients. Clearly, large controlled randomized trials are necessary to define the issue of cardiomyoplasty as a temporary approach, before more radical interventions such as heart transplantation can be used in selected patients with refractory Chagas' heart disease ${ }^{7}$.

Prevention of thromboembolic events - There is very limited clinical information concerning the risk of embolic phenomena in patients with detected mural thrombus or apical aneurysm ${ }^{7}$. In 65 selected patients with apical aneurysm a follow-up study ranging from 19 to 176 months documented 17 episodes of thromboembolism occurring in 14 patients $(24.5 \%)^{181}$. These patients also had congestive heart failure, and 11 died in the period of observation. In eight of those patients the cause of death was related to heart failure, and in three it was a consequence of cerebral embolism. Another small study addressed the relative contribution of Chagas' heart disease as the underlying cause of embolism in 69 patients with embolic strokes treated in an endemic region in South America ${ }^{182}$. Of 13 patients with nonischemic dilated cardiomyopathy, Chagas' heart disease was detected in $9(13.0 \%)$. It was the third more frequently identified cause of embolism, just after atrial 
fibrillation (29\%) and rheumatic valvular heart disease $(20.3 \%)$.

However, the real risk of thromboembolism in patients with Chagas' heart disease is unknown, as no specific studies have addressed this problem. Furthermore, despite the preliminary evidence that thromboembolic events are relevant prognostic factors in the natural history of Chagas' disease, no clinical studies focusing on adequate treatment and prevention of thromboembolism in chagasic patients have been conducted to date ${ }^{7}$.

Current recommendations for anticoagulant therapy are based on information derived from other dilated cardiomyopathies. Chagasic patients presenting global LV dysfunction, atrial fibrillation, previous embolic episodes, dyskinetic areas with detected mural thrombus, are candidate to treatment with intravenous and/or oral anticoagulants ${ }^{183}$. The issue is further complicated by the fact that social and economic factors limit the implementation of this strategy, even in chagasic patients with otherwise apparent clear indications for prevention of thromboembolic events ${ }^{7}$.

Management of chagasic patients with precordial pain - This may be a difficult task, and is entirely empirically based. The symptom is not related to vasotonic angina and recent studies show that chagasic patients do not have augmented responses to either coronary constrictor or endothelium-independent vasodilator stimuli, suggesting that no increased baseline coronary tonus occurs ${ }^{144,184}$. Also, therapeutic interventions aiming at the relief of symptoms as possibly derived from esophageal involvement are not usually justifiable. Although endoscopy evidence of esophagitis can be obtained in a substantial proportion of chagasic patients, their sensitivity to chemical or mechanical stimuli is typically depressed ${ }^{185}$. Some patients benefit from the use of nitrates and beta-adrenergic or calcium channel blockers, but the individual response is unpredictable.

Management of rhythm disturbances -Management of symptomatic bradyarrhythmias does not differ from that recommended for other cardiomyopathies, and in most situations relies on permanent pacemaker insertion, but no sound evidence based on large randomized controlled trials is available to support any specific treatment strategy ${ }^{7}$.

Main indications for pacing are atrioventricular block and sinus node dysfunction ${ }^{186}$. The evidence for a beneficial effect of pacemaker implantation comes from the superior clinical outcome of patients with such rhythm disturbances in limited case-series reports, as compared with the natural history of patients in whom this treatment was not possible ${ }^{187,188}$. Another relevant aspect is the common association of atrioventricular disturbances and ventricular complex dysrhythmia in the same patient. The acceptable management of this clinical condition requires "prophylactic" artificial pacemaker implantation associated with pharmacological antiarrhythmic therapy, even though this combined strategy is not based on adequate evidence.

For patients with asymptomatic ventricular ectopic beats or nonsustained ventricular tachycardia no definite antiarrhythmic therapy was shown to improve survival ${ }^{7}$. Indeed, very scanty information has been published regarding this issue, but two moderately large randomized trials included chagasics among patients treated with amiodarone ${ }^{189,190}$.

The GESICA (Grupo de Estudio de la Sobrevida en la Insuficiencia Cardiaca en Argentina) ${ }^{189}$ concluded, after two years of follow-up, that low-dose amiodarone was effective in reducing mortality and hospital admission in patients with severe heart failure, independent of the presence of complex ventricular dysrhythmia. Unfortunately, the contingent of chagasic patients was very small (48 of 516 patients), and subgroup analysis was neither provided nor would likely be useful.

An ongoing prospective multicenter randomized controlled study designed to evaluate the impact on survival of treatment of asymptomatic ventricular arrhythmia also included chagasic patients ${ }^{190}$. In its pilot phase this trial enrolled 127 patients ( 24 with Chagas' heart disease) with LVEF $<35 \%$, presenting frequent ventricular premature complexes and/or repetitive forms of asymptomatic ventricular arrhythmia. The preliminary results after 12 months of follow-up showed a significant reduction in the incidence of sudden death in the amiodarone group (7.0\% vs $20.4 \%)$. It must be pointed out that follow-up data were obtained in only 106 patients. This was a consequence of an excessively high drop-out rate (16\%) which seriously limits the appraisal of the results. Nevertheless, we should await the final results of this trial, hopefully recruiting a larger contingent of chagasic patients, before the routine use of amiodarone could be recommended for chagasic patients with asymptomatic ventricular arrhythmias.

Although no prospective controlled studies with antiarrhythmic drugs have been performed for treatment of hemodynamically tolerated sustained VT in the setting of Chagas' heart disease, those patients are generally treated with class III anti-arrhythmic drugs, either amiodarone (1000mg/day for 10 to 14 days followed by maintenance therapy at 200 to $600 \mathrm{mg} /$ day) ${ }^{191}$ or sotalol (320mg/day) after electrophysiologic study ${ }^{192}$. The efficacy of empiric treatment with amiodarone is strongly influenced by the grade of left ventricular dysfunction. This is reflected in one-year mortality rates of 0 and 40 percent and of recurrence of ventricular tachycardia of 30 and 100 percent after one year, respectively for groups of chagasics with class I-II and III-IV of the NYHA ${ }^{42,191}$.

Patients at high risk of sudden death from lethal tachyarrhythmias would probably benefit from an implantable cardioverter-defibrillator ${ }^{8,193}$, but its widespread use is hampered by socioeconomic limitations. Aneurys-mectomy or cryosurgical ablation following electrophysio-logic study, have been indicated for patients with ventri-cular tachycardia refractory to medical treatment, particular-ly those in whom a structural lesion can be spotted ${ }^{194}$. 
Preliminary evidence shows efficacy of approximately 60 percent in such group ${ }^{194}$.

Sustained monomorphic ventricular tachycardia (VT) may also be amenable to percutaneous ablation using catheter-delivered radiofrequency in selected patients with inducible, hemodynamically tolerated VT and identifiable sites of the reentry circuits ${ }^{195-199}$. One of these studies reported that after endocardial radiofrequency ablation in 15 patients, only 4 (27\%) patients were free of induced ventricular tachycardia ${ }^{195}$. In $5(33 \%)$ patients VT was favorably modified and the procedure was unsuccessful in $6(40 \%)$ patients. Antiarrhythmic drugs were continued in 14 (93\%) patients. On a 2-year follow-up, VT recurrence rate and mortality were significantly reduced in patients whose VT was suppressed or modified by endocardial radiofrequency ablation, in comparison with those patients in whom ablation was considered unsuccessful. However, another study described that after endocardial radiofrequency and/or low energy direct current ablation in 24 patients, whereas suppression or modification of VT was achieved in 19 (79\%) patients, successful clinical outcome was obtained in only $4(17 \%)$ patients on a follow-up of $26 \pm 21$ months ${ }^{196}$. Moreover, only $2(8 \%)$ patients were off all antiarrhythmic drugs and $4(17 \%)$ patients also required other nonpharmacological therapy.

Thus, because endocardial radiofrequency ablation could only be performed in selected patients with hemodynamically tolerated VT and more than 90 percent of patients still need antiarrhythmic drug therapy after ablation, endocardial radiofrequency ablation should still be regarded more as a potential ancillary therapy than a curative procedure for $\mathrm{VT}^{197}$.
More recent studies suggest that progress in ablation of chagasic VT might be made following new mapping techniques of VT such as epicardial mapping through the coronary venous system ${ }^{198}$ or nonsurgical transthoracic epicardial mapping through pericardial puncture ${ }^{199}$. This later investigation found a high prevalence of epicardial reentrant circuits in chagasic VT, reporting that of 10 consecutive patients who underwent transthoracic epicardial mapping, VT was rendered noninducible in all six patients in whom epicardial ablation was attempted ${ }^{199}$. In contrast, unsuccessful ablation and clinical outcome occurred in the four patients in whom epicardial-guided endocardial delivery of radiofrequency energy was performed.

Clearly, the preliminary experience with such approaches must be expanded, on an investigational basis, to define their relative value for arrhythmia control and mortality reduction.

In summary, pharmacological, surgical and devicebased strategies for the treatment of ventricular dysrhythmia in chagasic patients are empirical and not supported by large randomized controlled trials ${ }^{7}$. For chagasic patients with symptomatic bradyarrhythmias it is generally agreed that a permanent pacemaker should be inserted. For patients with unstable ventricular tachyarrhythmias an implantable cardioverter-defibrillator should be primarily considered. Catheter-based or surgical ablative therapy should be considered investigational procedures, for selected patients with good hemodynamic tolerance during ventricular tachycardia. For patients with asymptomatic ventricular premature beats or nonsustained ventricular tachycardia no antiarrhythmic therapy would generally be required ${ }^{200}$.

\section{References}

1. Guhl F, Jaramillo C, Yockteng R, Vallejo GA, Cardenas-Arroyo F. Trypanosoma cruzi DNA in human mummies. Lancet 1997: 10; 349: 1370.

2. Adler S. Darwin's illness. Nature 1959; 184: 1102-3.

3. Chagas C. The discovery of Trypanosoma cruzi and of American Trypanosomiasis. Mem Inst Oswaldo Cruz 1922; 15: 1.

4. Ming M, Ewen ME, Pereira ME, et al. Trypanosome invasion of mammalian cells requires activation of the TGF beta signaling pathway. Cell 1995; 82: 287-9.

5. Schmunis GA, Zicker F, Moncayo A. Interruption of Chagas' disease transmission through vector elimination. Lancet 1996; 348: 1171.

6. Wanderley DMV, Corrêa FMA. Epidemiology of Chagas' heart disease. S,,o Paulo Med J 1995; 113: 742-9.

7. Marin-Neto JA, Simões MV, Maciel BC. Specific diseases: cardiomyopathies and pericardial diseases. Other cardiomyopathies. In: Yusuf S, Cairns J, Camm J, Fallen E, Gersh BJ, eds. - Evidence Based Cardiology. London, GB: BMJ Books, Brit Med Association, 1998: 744-61

8. Hagar JM, Rahimtoola SH. Chagas' heart disease in the United States. N Engl J Med 1991; 325: 763-8.

9. Schmunis GA. Trypanosoma cruzi, the etiologic agent of Chagas disease: status of blood supply in endemic and nonendemic countries. Transfusion 1991; 31: 547-57.

10. Schofield CJ, Dias JCP. A cost benefit analysis of Chagas disease control. Mem Inst Oswaldo Cruz 1991; 86: 285-95.

11. Hamerschlak N, Pasternak J, Amato Neto V, et al. Chagas' disease: an algorithm for donor screening and positive donor counseling. Rev Soc Bras Med Trop 1997; 205-9.
12. Salles NA, Sabino EC, Cliquet MG, et al. Risk of exposure to Chagas' disease among seroreactive Brazilian blood donors. Transfusion 1996; 36: 969-73.

13. Ramirez LE, Lages-Silva E, Pianetti GM, Rabelo RM, Bordin JO, Moraes-Souza $\mathrm{H}$ - Prevention of transfusion-associated Chagas' disease by sterilization of Trypanosoma cruzi-infected blood with gentian violet, ascorbic acid, and light. Transfusion 1995; 35: 226-30.

14. Acquatella H, Catalioti F, Gomez-Mancebo JR, Davalos V, Villalobos L. Longterm control of Chagas disease in Venezuela: effects on serologic findings, electrocardiographic abnormalities, and clinical outcome. Circulation 1987; 76: 556-62.

15. Basombrio MA, Schofield CJ, Rojas CL, del Rey EC. A cost-benefit analysis of Chagas' disease control in north-western Argentina. Trans R Soc Trop Med Hyg 1998; 92: 137-43.

16. Costa FC, Vitor RW, Antunes CM, Carneiro M. Chagas' disease control programme in Brazil: a study of the effectiveness of 13 years of intervention. Bull World Health Organ 1998; 76: 385-91.

17. Dias JC, Schofield CJ. The control of the transmission by transfusion of Chagas' disease in the southern cone initiative. Rev Soc Bras Med Trop 1998; 31: 373-83.

18. Marsden PD. The control of Latin American trypanosomiasis. Rev Soc Bras Med Trop 1997; 30: 521-7.

19. Ciaravolo RM, Domingos M de F, Wanderley DM, et al. Autochthonous acute Chagas' disease in São Paulo State, Brazil: epidemiological aspects. Rev Inst Med Trop São Paulo 1997; 39: 171-4.

20. Ianni BM, Mady C. The indeterminate form of Chagas'disease. Myths vs facts Arq Bras Cardiol 1997; 68: 147-8. 
21. Ribeiro AL, Rocha MO. Indeterminate form of Chagas' disease: considerations about diagnosis and prognosis. Rev Soc Bras Med Trop 1998; 31: 301-14.

22. Simies MV, Soares FA, Marin-Neto JA. Severe myocarditis and esophagitis, during reversible long standing Chagas'disease recrudescence in immunocompromised host. Int J Cardiol 1995; 49: 271-3.

23. Sartori AM, Shikanai-Yasuda MA, Amato Neto V, Lopes MH. Follow-up of 18 patients with human immunodeficiency virus infection and chronic Chagas' disease, with reactivation of Chagas' disease causing cardiac disease in three patients. Clin Infect Dis 1998; 26: 177-9.

24. Ferreira MS, Nishioka S de A, Silvestre MT, Borges AS, Nunes-Araujo FR, Rocha A. Reactivation of Chagas' disease in patients with AIDS: report of three new cases and review of the literature. Clin Infect Dis 1997; 25: 1397-400.

25. Sartori AM, Lopes MH, Benvenuti LA, et al. Reactivation of Chagas' disease in a human immunodeficiency virus-infected patient leading to severe heart disease with a late positive direct microscopic examination of the blood. Am J Trop Med Hyg 1998; 59: 784-6.

26. Parada H, Carrasco HA, Añez N, Fuenmayor C, Inglessis I. Cardiac involvement is a constant finding in acute Chagas' disease: a clinical, parasitological and histopathological study. Int J Cardiol 1997; 60: 49-54.

27. Dias JCP. Cardiopatia chagásica: História Natural. In: Cançado JR, Chuster M, eds. Cardiopatia Chagásica. Belo Horizonte, MG: Fundação Carlos Chagas de Pesquisa Médica, 1985: 99-113.

28. Dias JCP. The indeterminate form of human chronic Chagas' disease. A clinical epidemiological review. Rev Soc Bras Med Trop 1989; 22: 147-56.

29. Zicker F, Smith PG, Almeida Netto JC, Oliveira RM, Zicker SEM. Physical activity, opportunity for reinfection, and sibling history of heart disease as risk factors for Chagas' cardiopathy. Am J Trop Med Hyg 1990; 43: 498-505.

30. Macedo V. Forma indeterminada da doença de Chagas - J Bras Med 1980; 38: 34-40.

31. Forichon E. Contribuition aux estimations de morbidité et de mortalité dans la maladie de Chagas (Tèse Univers.). Toulouse, France: Paul-Sabatier, 1974: 47p.

32. Puigbó JJ, Rhode JRN, Barrios HG, Yépez CG. A 4-year follow-up study of a rural community with endemic Chagas' disease. Bull. World Health Organ 1968; 39 : 341-8.

33. MotaEA, Guimarães AC, Santana OO, Sherlock I, Hoff R, Weller TH. A nine year prospective study of Chagas' disease in a defined rural population in northeast Brazil. Am J Trop Med 1990; 42: 429-40.

34. Dias JCP, Kloetzel K. The prognostic value of the electrocardiographic features of chronic Chagas' disease. Rev Inst Med Trop São Paulo 1968; 10: 158-62.

35. Maguire JH, Mott KE, Lehman JS, et al. Relationship of electrocardiographic abnormalities and seropositivity to Trypanosoma cruzi within a rural community in Northeast Brazil. Am Heart J 1983; 105: 287-94.

36. Coura JR, Abreu LL, Pereira JB, Willcox HP. Morbidade da doença de Chagas.IV. Estudo longitudinal de dez anos em Pains e Iguatama, Minas Gerais. Mem Inst Oswaldo Cruz 1985; 80: 73-80.

37. Pereira JB, Cunha RV, Willcox HP, Coura JR - Development of chronic human Chagas' cardiopathy in the hinterland of Paralba, Brazil, in a 4.5 year period. Rev Soc Bras Med Trop 1990; 23: 141-7.

38. Pugliese C, Lessa I, Santos Filho A. Estudo da sobrevida na miocardite crônica de Chagas descompensada. Rev Inst Med Trop São Paulo 1976; 18: 191-201.

39. Espinosa R, Carrasco HA, Belandria F, et al. Life expectancy analysis in patients with Chagas' disease: prognosis after one decade (1973-1983). Int J Cardiol 1985; 8: 45-56

40. Mady C, Cardoso RHA, Barreto ACP, Luz PL, Bellotti G, Pileggi F. Survival and predictors of survival in congestive heart failure due to Chagas' cardiomyopathy. Circulation 1994; 90: 3098-102.

41. de-Paola AA, Gomes JA, Terzian AB, Miyamoto MH, Martinez $F^{\circ}$ EE. Ventricular tachycardia on exercise testing is significantly associated with sudden cardiac death in patients with chronic chagasic cardiomyopathy and ventricular arrhythmias. Br Heart J 1995; 74: 293-5.

42. Marin-Neto JA, Maciel BC, Simões MV. Chagas' heart disease. In: Rose BD, Podrid PJ, Gersh BJ, eds. - UpToDate in Cardiovascular Medicine, a CD-ROM Textbook. Vol6. Wellesley, MA, USA: UpToDate in Medicine, Inc., February 1998.

43. Laranja FS, Dias E, Nobrega G, Miranda A. Chagas' disease: a clinical, epidemiologic, and pathologic study. Circulation 1956; 14: 1035-59.

44. Lopes ER, Chapadeiro E, Almeida HO, Rocha A, Rocha A. Contribuição ao estudo da anatomia patológica dos corações de chagásicos falecidos subitamente. Rev Soc Bras Med Trop 1975; 9: 269-82.

45. Garzon SAC, Lorga AM, Ferreira JGS, et al. Cardiopatia chagásica sem sinais clínicos de cardiopatia. Arq Bras Cardiol 1975; 28: 232-42.

46. Barreto ACP, Arteaga-Fernandez E. RV endomyocardial biopsy in chronic Chagas' disease. Am Heart J 1986; 111: 307-12.

47. Marin-Neto JA, Marzullo P, Marcassa C, et al. Myocardial perfusion defects in chronic Chagas' disease. Assessment with thallium-201 scintigraphy. Am J Cardiol 1992; 69: 780-4

48. Barreto ACP, Ianni BM. The undetermined form of Chagas' heart disease: concept and forensic implications. São Paulo Med J 1995; 113: 797-801.
49. Oliveira JSM. A natural human model of intrinsic heart nervous system denervation: Chagas' cardiopathy. Am Heart J 1985; 110: 1092-8.

50. Oliveira JSM, Araújo RRC, Mucillo G. Cardiac thrombosis and thromboembolism in chronic Chagas' heart disease. Am J Cardiol 1983; 52: 147-51.

51. Prata A, Andrade Z, Guimarães AC. Chagas' heart disease. In: Shaper AG, Hutt MSR, Fejfar Z, eds. - Cardiovascular Disease in the Tropics. London: British Medical Association, 1974: 264-81.

52. Rassi Jr A, Rassi AG, Rassi SG, et al. Arritmias ventriculares na doença de Chagas. Particularidades diagnósticas, prognósticas e terapêuticas. Arq Bras Cardiol 1995; 65: 377

53. Marin-Neto JA, Marzullo P, Ayres-Neto EM, et al. Myocardial perfusion disturbances detected by ${ }^{99 \mathrm{~m}} \mathrm{Tc}$-microspheres in Chagas' patients with angiographically normal coronary arteries. Circulation 1995; 92: I-471.

54. Hammersmeister KE, Caeiro T, Crespo E, Palmero H, Gibson DG. Left ventricular wall motion in patients with Chagas's disease. Br Heart J 1984; 51: 70-6.

55. Feit A, El-Sherif N, Korostoff S. Chagas' disease masquerading as coronary artery disease. Arch Intern Med 1983; 143: 144-5.

56. Simões MV, Ayres-Neto EM, Santos JLA, et al. Síndromes anginóides agudas em portadores de Moléstia de Chagas: avaliação prospectiva de 7 casos. Rev Soc Cardiol Est SP 1995; 5: 31.

57. Ferreira AW, Avila SLM. Laboratory diagnosis of Chagas' heart disease. S,,o Paulo Med J 1995; 113: 767

58. Degrave WM. Molecular diagnosis of Chagas disease. In: Wendel S, Brener Z, Camargo ME, Rassi A, eds. - Chagas Disease (American Trypanosomiasis): Its Impact on Transfusion and Clinical Medicine. S,,o Paulo, Brazil: ISBT Brazil, 1992: 225 .

59. Britto C, Cardoso MA, Vanni CM, et al. Polymerase chain reaction detection of Trypanosoma cruzi in human blood samples as a tool for diagnosis and treatment evaluation. Parasitology 1995; 110: 241-7.

60. Montamat EE, De Luca D' Oro GM, Gallerano RH, Sosa R, Blanco A. Characterization of Trypanosoma cruzi populations by zymodemes: correlation with clinical picture. Am J Trop Med Hyg 1996; 55: 625-8.

61. Garzon SAC, Lorga AM, Nicolau JC. Electrocardiography in Chagas' heart disease. São Paulo Med J 1995; 113: 802-13.

62. Grupi CJ, Moffa PJ, Barbosa AS, et al. Holter monitoring in Chagas' heart disease São Paulo Med J 1995; 113: 835-40.

63. Maciel BC, Almeida-Filho OC, Schmidt A, Marin-Neto JA. Ventricular function in Chagas' heart disease. São Paulo Med J 1995; 113: 814-20.

64. Simões MV, Ayres Neto EM, Attab dos Santos JL, et al. Detecção de isquemia miocárdica em chagásicos crônicos com precordialgia atípica pelos testes de esforço e Holter. Arq Bras Cardiol 1993; 60: 315.

65. Sgammini HO, Kuschnir E, Evequoz MC, Marin-Neto JA. Evaluation of severe ventricular arrhythmias in chronic Chagas' heart disease by effort test and Holter monitoring. Braz J Med Biol Res 1985; 18: 285.

66. Gallo Jr L, Marin-Neto JA, ManÁo JC, Rassi A, Amorim DS. Abnormal heart rate responses during exercise in patients with Chagas'disease. Cardiology 1975; 60: 147-62.

67. Gallo Jr L, Morelo-Filho J, Maciel BC, Marin-Neto JA, Martins LEB, Lima-Filho EC. Functional evaluation of sympathetic and parasympathetic system in Chagas' disease using dynamic exercise. Cardiov Res 1987; 21: 922-7.

68. Marin-Neto JA, Marzullo P, Sousa ACS, et al. Radionuclide angiographic evidence for early predominant right ventricular involvement in patients with Chagas' disease. Can J Cardiol 1988; 4: 231-6.

69. Marin-Neto JA, Bromberg-Marin G, Pazin-Filho A, Simões MV, Maciel BC. Cardiac autonomic impairment and early myocardial damage involving the right ventricle are independent phenomena in Chagas' disease. Int J Cardiol 1998; 65: 261-9.

70. De Paola AAV, Horowitz LN, Miyamoto MH, et al. Angiographic and electrophysiologic substrates of ventricular tachycardia in chronic chagasic myocarditis. Am J Cardiol 1990; 65: 360.

71. Scanavacca M, Sosa EA. Electrophysiologic study in chronic Chagas' heart disease. São Paulo Med J 1995; 113: 841-50.

72. Moraes AP, Moffa PJ, Sosa EA, et al. Signal-averaged electrocardiogram in chronic Chagas' heart disease. São Paulo Med J 1995; 113: 851-7.

73. Carrasco-GH, Jugo D, Medina R, Castillo C, Miranda P. Electrocardiograma de alta resolución y variabilidad de la frecuencia cardiaca en pacientes chagásicos crónicos. Arch Inst Cardiol Méx 1997; 67: 277-85.

74. Kalil Filho R, de Albuquerque CP. Magnetic resonance imaging in Chagas' heart disease - Rev Paul Med 1995; 113: 880-3

75. Marin-Neto JA, Gallo L Jr, Manço JC, Rassi A, Amorim DS. Mechanisms of tachycardia on standing: studies in normal individuals and in chronic Chagas' heart patients. Cardiovasc Res 1980; 14: 541-50.

76. Sousa ACS, Marin-Neto JA, Maciel BC, Gallo Jr L, Amorim DS. Cardiac parasympathetic impairment in gastrointestinal Chagas' disease. Lancet 1987; I 8539: 985.

77. Amorim DS, Marin-Neto JA. Functional alterations of the autonomic nervous system in Chagas' heart disease. São Paulo Med J 1995; 113: 772-83. 
78. Marin-Neto JA. Etiology and pathogenesis of Chagas'disease. In: Rose BD Podrid PJ, Gersh BJ, eds. - Uptodate in Cardiovascular Medicine, a CD-ROM Textbook. Vol.6. Wellesley, MA, USA:UpToDate in Medicine, Inc., February 1998.

79. K^berle F .Enteromegaly and cardiomegaly in Chagas' disease. Gut 1963; 4: 399-405.

80. Mott KE, Hagstrom JWC. The pathologic lesions of the cardiac autonomic nervous system in chronic Chagas' myocarditis. Circulation 1965; 31: 273-86.

81. Alcântara FG. Denervação dos gânglios cardíacos intramurais e cervicotorácicos na moléstia de Chagas. Rev Goiana Med 1970; 16: 159-77.

82. Köberle F. Chagas' heart disease and Chagas' syndromes: the pathology of American trypanosomiasis. Adv Parasitol 1968; 6: 63-116.

83. Okumura M, Brito T, Pereira da Silva LH, et al. The pathology of experimenta Chagas' disease in mice. I. Digestive tract changes with special reference to necrotizing arteritis. Rev Inst Med Trop S,,o Paulo 1960; 2: 17.

84. Kumar R, Kline L, Abelman W. Experimental Trypanosoma cruzi myocarditis. Relative effects upon the right and left ventricles. Am J Pathol 1969; 57: 31

85. Teixeira ARL, Teixeira L, Santos-Buch CA. The immunology of experimenta Chagas' disease. IV. The production of lesions in rabbits similar to those of chronic Chagas' disease in man. Am J Pathol 1975; 80: 163.

86. Andrade ZA. The canine model of Chagas' disease. Mem Inst Oswaldo Cruz 1984; 79(suppl): 77.

87. Carrasco-Guerra HA, Palacios-Pr, E, Scorza CD, et al. Clinical, histochemica and ultrastructural correlation in septal endomyocardial biopsies from chronic chagasic patients: Detection of early myocardial damage. Am Heart J 1987; 113: 716-24.

88. Oliveira JSM, Oliveira JAM, Frederigue Jr U, Lima-Filho EC. Apical aneurysm of Chagas's heart disease. Br Heart J 1981; 46: 432-7.

89. Andrade ZA. The canine model of Chagas' disease. Mem Inst Oswaldo CruZ 1984; 79(suppl): 77.

90. Rossi MA. Patterns of myocardial fibrosis in idiopathic cardiomyopathies and chronic Chagasic cardiopathy. Can J Cardiol 1991; 7: 287-94.

91. Lopes ER, Tafuri WL. Involvement of the autonomic nervous system in Chagas' heart disease. Rev Soc Bras Med Trop 1983; 16: 206.

92. Mott KE, Hagstrom JWC. The pathologic lesions of the cardiac autonomic nervous system in chronic Chagas' myocarditis. Circulation 1965; 31: 273-86.

93. Baroldi G, Oliveira SJ, Silver MD. Sudden and unexpected death in clinically "silent" Chagas'disease. A hypothesis. Int J Cardiol 1997; 58: 263-8.

94. Carrasco HA, Guerrero L, Parada H, Molina C, Vegas E, Chuecos R. Ventricula arrhythmias and left ventricular myocardial function in chronic chagasic patients. Int J Cardiol 1990; 28: 35-41.

95. Sosa E, Scanavacca M, Marcial MB, et al. Tratamento cirúrgico das arritmias cardíacas. In: Cruz Filho FES, Maia IG, eds. - Eletrofisiologia Clínica e Intervencionista das Arritmias Cardíacas. Rio de Janeiro: Revinter, 1997: 443-54.

96. Amorim DS, Manço JC, Gallo L Jr, Marin-Neto JA. Chagas' heart disease as an experimental model for studies of cardiac autonomic function in man. Mayo Clin Proc 1982; 57: 48-60.

97. Machado CR, Caliari MV, de Lana M, Tafuri WL. Heart autonomic innervation during the acute phase of experimental American trypanosomiasis in the dog. Am J Trop Med Hyg 1998; 59: 492-6.

98. Camargo ER, Haertel LR, Machado CR. Preganglionic fibres of the adrenal medulla and cervical sympathetic ganglia:differential involvement during experimental American trypanosomiasis in rats. Int J Exp Pathol 1996; 77: 115-24.

99. De Souza MM, Andrade SG, Barbosa AA Jr, Macedo dos Santos RT, Ferreira Alves VA, Andrade ZA. Trypanosoma cruzi strains and autonomic nervous system pathology in experimental Chagas disease. Mem Inst Oswaldo Cruz 1996; 91: 217-24.

100. Meneghelli UG. Chagas' disease: a model of denervation in the study of digestive tract motility. Brazilian J Med Biol Res 1985; 18: 255-64.

101. Ribeiro AL. Autonomic dysfunction and ventricular arrhythmia in Chagas disease patients without apparent cardiac involvement. Rev Soc Bras Med Trop 1997; 30: 257-8

102. Dávila DF, Inglessis G, Dávila CAM. Chagas' heart disease and the autonomic nervous system. Int J Cardiol 1998; 66: 123-7.

103. Marin-Neto JA. Cardiac dysautonomia and pathogenesis of Chagas' heart disease. Int J Cardiol 1998; 66: 129-31

104. Giorgi MCP. Avaliação cintilográfica da inervação cardíaca simpática e da perfusão miocárdica na doença de Chagas (Tese de Doutorado). São Paulo: Faculdade de Medicina da USP, 1997: 89p.

105. Simões MV, Pintya AO, Sarabanda AV, Pazin-Filho A, Maciel BC, Marin-Neto JA. Reduced [ ${ }^{123}$ I]MIBG uptake precedes wall motion impairment in Chagas' disease. J Nucl Cardiol 1999 (printing).

106. Simões MV, Pintya AO, Sarabanda AV, Maciel BC, Bromberg-Marin G, MarinNeto JA. Assessment of cardiac sympathetic activity in Chagas' cardiomyopathy using [ [23] MIBG scintigraphy. J Nucl Cardiol 1999 (printing).

107. Ribeiro dos Santos R, Marquez, JO, Von Gal Furtado CC, Ramos de Oliveira JC Martins AR, Köberle F. Antibodies against neuros in chronic Chagas' disease. Tropenmed Parasitol 1979; 30: 19-23.
108. Sterin-Borda LJ, Borda ES. Participation of autonomic nervous system in the pathogenesis of Chagas' disease. Acta Physiol Pharmacol Thera Latinoam 1994; 44: 109-23

109. Borda ES, Sterin-Borda L. Antiadrenergic and muscarinic receptor antibodies in Chagas' cardiomayopathy. Int J Cardiol 1996; 54: 149-56.

110. Cremaschi G, Zwirner NW, Gorel B, et al. Modulation of cardiac physiology by an anti-Trypanosoma cruzi monoclonal antibody after interaction with myocardium. FASEB J 1995: 9: 1482-8.

111. Oliveira SF, Pedrosa RC, Nascimento JH, Campos de Carvalho AC, Masuda MO. Sera from chronic chagasic patients with complex cardiac arrhythmias depress electrogenesis and conduction in isolated rabbit hearts. Circulation 1997; 16: 2031-7.

112. Ramos SG, Matturri L, Rossi L, Rossi MA. Lesions of mediastinal paraganglia in chronic chagasic cardiomyopathy: cause of sudden death? Am Heart J 1996; 131: 417-20.

113. Higuchi ML, DeBrito T, Reis MM, et al. Correlation between T.cruzi parasitism and myocardial inflammatory infiltrate in human chronic chagasic myocarditis: light microscopy and immunohistochemical findings. Cardiovasc Pathol 1993; 2: 101-6.

114. Brener Z. O parasito: relações hospedeiro-parasito. In: Brener Z, Andrade ZA, eds. - Trypanosoma cruzi e Doença de Chagas. Rio de Janeiro: Guanabara Koogan, 1979: 1-41.

115. Bellotti G, Bocchi EA, Moraes AV, et al. In vivo detection of Trypanosoma cruzi antigens in hearts of patients with chronic Chagas' disease. Am Heart J 1996; 131: 301-7.

116. Jones EM, Colley DG, Tostes S, Lopes ER, Vnencak-Jones CL, McCurley TL. A Trypanosoma cruzi DNA sequence amplified from inflammatory lesions in human chagasic cardiomyopathy. Trans Assoc Am Physicians 1992; 105: 182-9.

117. Avila HA, Sigman DS, Cohen LM, Millikan RC, Simpson L. Polymerase chain reaction amplification of Trypanosoma cruzi kinetoplast minicircle DNA isolated from whole blood lysates: diagnosis of chronic Chagas' disease. Mol Biochem Parasitol 1991; 48: 211-21.

118. Wincker P, Telleria J, Bosseno MF, et al. PCR-based diagnosis for Chagas' disease in Bolivian children living in an active transmission area: comparison with conventional serological and parasitological diagnosis. Parasitology 1997; 114: 367-73.

119. Higuchi ML. Chronic chagasic cardiopathy: the product of a turbulent hostparasite relationship. Rev Inst Med Trop São Paulo 1997; 39: 53-60.

120. Cunha-Neto E, Kalil J. Autoimmunity in Chagas' heart disease. São Paulo Med J 1995; 113: 757-66

121. Higuchi ML, Ries MM, Aiello VD, et al. Association of an increase in CD8+ T cells with the presence of Trypanosoma cruzi antigens in chronic human chagasic myocarditis. Am J Trop Med Hyg 1997; 56: 485-9.

122. Fragata-Filho AA, Dias da Silva MA, Boainaim E. Ethiological treatment of acute and chronic Chagas' heart disease. Rev Soc Cardiol Estado de São Paulo 1994; 4: 192-7.

123. Viotti R, Vigliano C, Armenti H, Segura E. Treatment of chronic Chagas' disease with benznidazole: clinical and serologic evolution of patients with long-term follow-up. Am Heart J 1994; 127: 151-62.

124. Apt W, Aguilera X, Arribada A, et al. Treatment of chronic Chagas' disease with itraconazole and allopurinol. Am J Trop Med Hyg 1998; 59: 133-8.

125. Morris SA, Tanowitz HB, Wittner M, Bilezikian JP. Pathophysiological insights into the cardiomyopathy of Chagas' disease. Circulation 1990; 82: 1900-9.

126. Rossi MA. Microvascular changes as a cause of chronic cardiomyopathy in Chagas' disease. Am Heart J 1990; 120: 233-6.

127. Torres CM. Miocitólise e fibrose do miocárdio na doença de Chagas. Mem Inst Oswaldo Cruz 1960; 58: 161-82.

128. Torres CM. Arterioloesclerose das finas ramificações arteriais do miocárdio (coronarite chagásica) e miocitólise focal do miocárdio na cardiopatia chagásica crônica. O Hospital 1958; 54: 19-34.

129. Brito T, Vasconcelos E. Necrotizing arteritis in megaesophagus. Histopathology of minety-one biopsies taken from the cardia. Rev Inst Med Trop São Paulo 1959; 1: $195-206$.

130. Jörg ME. Tripanosomiasis cruzi: anarquia angiotopográfica por descapilarizacion mesenquimoreactiva, cofactor patogénico de la miocardiopatia crónica. Pren Med Argent 1974; 61: 94-106.

131. Okamura M, Brito T, Pereira-da-Silva LH, Carvalho-da-Silva A, Correa-Netto A The pathology of experimental Chagas' disease in mice: digestive tract changes, with reference to necrotizing arterites. Rev Inst Med Trop São Paulo 1960; 2: 17-28.

132. Factor SM, Sho S, WittnerM, Tanowitz H. Abnormalities of the coronary microcirculation in acute murine Chagas' disease. Am J Trop Med Hyg 1985; 34 246-53.

133. Rossi MA, Gon,calves S, Ribeiro-dos-Santos R. Experimental Trypanosoma cruzi cardiomyopathy in $\mathrm{BALB} / \mathrm{c}$ mice: the potential role of intravascular platele aggregation in its genesis. Am J Pathol 1984; 114: 209-16. 
134. Rossi MA, Carobrez SG. Experimental Trypanosoma cruzi cardiomyopathy in $\mathrm{BALB} / \mathrm{c}$ mice: histochemical evidence of hypoxic changes in the myocardium. $\mathrm{Br}$ J Exp Pathol 1985; 66: 155-60.

135. Morris SA, Weiss LM, Factor S, Bilezikian JP, Tanowitz HB, Wittner M. Verapamil amiliorates clinical, pathological and biochemical manifestations of experimental chagasic cardiomyopathy in mice. J Am Coll Cardiol 1989; 14: 782-9.

136. Kuschnir E, Épelman M, Kustich F, Santarnarina N, Podio RB. Valoración del fluxo miocárdico con $\mathrm{Rb} 86$, en pacientes con cardiopatia chagásica, con insuficiéncia coronaria y en controles normales. Parte 2: respuesta al ejercicio y a la cardiotonificación aguda. Arq Bras Cardiol 1974; 27: 721-32.

137. Rotondaro D, Castelletti LJ, Rios V, et al. Cambios en las imágenes de perfusión miocárdica con talio 201 en pacientes com miocardiopatía chagásica crónica, despues del tratamiento con dipiridamol. Arq Bras Cardiol 1979; 47: 129-36.

138. Meneghelo RS, Thom AF, Martins LRF. Aspectos da cintilografia miocárdica. In: Cançado JR, Chuster M, eds. Cardiopatia chagásica. Belo Horizonte: Fundação Carlos Chagas 1985: 184-7.

139. Kuschnir E, Kustich F, Epelman M, Podio RB. Efectos del dipiridamol sobre Ia funcion ventricular en pacientes con miocardiopatia chagásica crónica. Estudios con camara gamma computada. Rev Fed Arg Cardiol 1981; 10: 3-12.

140. Kuschnir E, Sgammini H, Castro R, Evequoz C, Ledesma R. Miocardiopatía chagásica crónica: effectos del dipiridamol sobre la dinámica ventricular. Arq Bras Cardiol 1983; 41:373-8.

141. Kuschnir E, Kustich F, Epelman MN, Podio RB. Estudios del flujo miocárdico en pacientes com insuficiéncia coronaria y en pacientes con cardiopatía chagásica crónica. Respuesta a la administración de dinitrato de isosorbide y dipiridamol. Pren Med Arg 1983; 60: 637-50.

142. Hagar JM, Tubau JF, Rahimtoola SH. Chagas' heart disease in USA: Thallium abnormalities mimic coronary artery disease. Circulation 1991; 84(suppl): II-631.

143. Torres FW, Acquatella H, Condado J, Dinsmore R, Palacios I. Coronary vascular reactivity is abnormal in patients with Chagas' heart disease. Am Heart J 1995; 129: 995-1001

144. Simões MV, Ayres-Neto EM, Attab-Santos JL, Maciel BC, Marin-Neto JA. Chagas' heart patients without cardiac enlargement have impaired epicardial coronary vasodilation but no vasotonic angina. J Am Coll Cardiol 1996; 27 : 394A-5A.

145. Andrade ZA, Andrade SG, Correa R, Sadigursky M, Ferrans VJ. Myocardial changes in acute Trypanosoma cruzi infection. Am J Pathol 1994; 144: 1403-11.

146. Cossio PM, Laguens RP, Diez C, Szarfman A. Segal A, Arana RM. Antibodies reacting to the plasma membrane of striated muscle and endothelial cells. Circulation 1974; 50: 1252-9.

147. Santos-Buch C, Acosta A, Zweerink H. Primary muscle disease: definition of a $25 \mathrm{kDa}$ polypeptide myopathic specific Chagas antigen. Clin Immunol Immunopathol 1985; 37: 334-50.

148. Acosta A, Santos-Buch C. Autoimmune myocarditis induced by Trypanosoma cruzi. Circulation 1985; 71: 1255-61.

149. Bonfá E, Viana W, Barreto ACP, Yoshinari N, Cossermelli W. Autoantibodies in Chagas' disease: an antibody cross-reactive with human and Trypanosoma cruzi ribosomal proteins. J Immunol 1993; 150: 3917-23.

150. Laguens RP, Argel MI, Chambo J, Storino R, Cabeza Meckert PM. Presence of antiheart and antiskeletal muscle glycolipid autoantibodies in the sera of patients with chagasic cardiopathy. Can J Cardiol 1994; 10: 769-76.

151. Davies JM. Molecular mimicry: can epitope mimicry induce autoimmune disease? Immunol Cell Biol 1997; 75: 113-26.

152. Rizzo LV, Cunha-Neto E, Teixeira A. Autoimmunity in Chagas' disease: Specific inhibition of reactivity of CD4+ T cells against myosin in mice chronically infected with Trypanosoma cruzi. Infect Immun 1989; 57: 2640.

153. Santos RR, Rossi MA, Laus JL, Santana-Silva J, Savino W, Mengel J. Anti-CD4 abrogates rejection and reestablishes long-term tolerance to syngeneic newborn hearts grafted in mice chronically infected with Trypanosoma cruzi. J Exp Med 1992; 175: 29-39.

154. Reis DD, Jones EM, Tostes S. Expression of major histocompatibility complex antigens and adhesion molecules in hearts of patients with chronic Chagas' disease. Am J Trop Med Hyg 1993; 49: 192-200.

155. Levin MJ, Mesri E, Benarous R. Identification of major Trypanosoma cruzi antigenic determinants in chronic Chagas' heart disease. Am J Trop Med Hyg 1989; 41: 530-8.

156. Cunha-Neto E, Duranti M, Gruber A, et al. Autoimmunity in Chagas' disease cardiopathy: biological relevance of a cardiac myosin-specific epitope crossreactive to an immunodominant Trypanosoma cruzi antigen. Proc Natl Acad Sci 1995; 92: 3541-5.

157. Laucella SA, de Titto EH, Segura EL. Epitopes common to Trypanosoma cruzi and mammalian tissues are recognized by sera from Chagas' disease patients: prognosis value in Chagas' disease. Acta Trop 1996; 62: 151-62.

158. Laderach D, Cerban F, Motran C, Vottero de Cima E, Gea S. Trypanosoma cruzi: the major cysteinyl proteinase (cruzipain) is a relevant immunogen of parasite acidic antigen (FIII). In J Parasitol 1996; 26: 1249-54.
159. Motran CC, Cerban FM, Rivarola W, Iosa D, Vottero de Cima E. Trypanosoma cruzi: immune response and functional heart damage induced in mice by the main linear B-cell epitope of parasite ribosomal P proteins. Exp Parasitol 1998; 88: 223-30.

160. Morrot A, Strickland DK, Higushi ML, Reis M, Pedrosa R, Scharfstein J. Human T cell responses against the major cysteine proteinase (cruzipain) of Trypanosoma cruzi: reole of the multifunctional alfa2-macroglobulin receptor in antigen presentation by monocytes. Intern Immunol 1997; 6: 825-34.

161. Rizzo LV, Cunha-Neto E, Teixeira A. Autoimmunity in Chagas'disease: Specific inhibition of reactivity of CD4+ T cells against myosin in mice chronically infected with Trypanosoma cruzi. Infect Immun 1989; 57: 2640.

162. Cunha-Neto E, Coelho VPC, Guilherme L, Fiorelli A, Stolf N, Kalil J. Autoimmunity in Chagas' disease: identification of cardiac myosin-B13 Trypanosoma cruzi protein crossreactive $\mathrm{T}$ cell clones in heart lesions of a chronic Chagas' cardiomyopathy patient. J Clin Invest 1996; 98: 1709-12.

163. Gorelik G, Cremaschi G, Borda E, Sterin-Borda L. Trypanosoma cruzi antigens down-regulate $\mathrm{T}$ lymphocyte proliferation by muscarinic choinergic-receptordependent release of PGE2. Acta Physiol Pharmacol Ther Latinoam 1998; 48 : 115-23.

164. Cunha-Neto E, Rizzo LV, Albuquerque F, et al. Cytokine production profile of heart-infiltrating T cell in Chagas' disease cardiomyopathy. Braz J Med Biol Res 1998; 31: 133-7.

165. Andrade ALSS, Zicker F, Oliveira RM, et al. Randomised trial of efficacy of benznidazole in treatment of early Trypanosoma cruzi infection. Lancet 1996; 348: 1407-13.

166. Coura JR, de Abreu LL, Willcox HP, Petana W. Comparative controlled study on the use of benznidazole, nifurtimox and placebo, in the chronic form of Chagas' disease, in a field area with interrupted transmission. I. Preliminary evaluation. Rev Soc Bras Med Trp 1997; 30: 139-44.

167. Bocchi EA, Higuchi ML, Vieira NL, et al. Higher incidence of malignant neoplasms after heart transplantation for treatment of chronic Chagas' heart disease. J Heart Lung Transplant 1998; 17: 399-405.

168. Almeida DR, Carvalho AC, Branco JN, et al. Chagas'disease reactivation after heart transplantation: efficacy of allopurinol treatment. J Heart Lung Transplant 1996; 15: 988-92.

169. Cerisola JA. Chemotherapy of Chagas' infection in man. Chagas' Disease Symposium Proceedings: 35-47.

170. Ferreira HO. Tratamento da "forma indeterminada" da doença de Chagas com nifurtimox e benzonidazol. Rev Soc Bras Med Trop 1990; 23: 209-11.

171. Andrade SG, Rassi A, Magalh,,es JB, Ferriolli Filho F, Luquetti AO. Specific chemoterapy of Chagas'disease: a comparison between the response in patients and experimental animals inoculated with the same strains. Trans Royal Soc Trop Med and Hyg 1992; 86: 624-6.

172. Batlouni M, Barretto AC, Armaganijan D, et al. Treatment of mild and moderate cardiac failure with captopril. A multicenter trial. Arq Bras Cardiol 1992: 58: 417-21.

173. Roberti RR, Martinez EE, Andrade JL, et al. Chagas cardiomyopathy and captopril. Eur Heart J 1992; 13: 966-70.

174. Khoury AM, Davila DF, Bellabarba G, et al. Acute effects of digitalis and enalapril on the neurohormonal profile of chagasic patients with severe congestive heart failure. Int J Cardiol 1996; 57: 21-9.

175. Simões MV, Pazin-Filho A, Bromberg-Marin G, Maciel BC, Marin-Neto JA. Early myocardial damage detected by radionuclide angiography evaluation of patients with the indeterminate phase of Chagas' disease. J Am Coll Cardiol 1998; 31(suppl C): 339C

176. Maciel BC, Almeida-Filho OC, Schmidt A, Marin-Neto JA. Mild segmental dyssynergy reflects more extensive myocardial involvement as compared to isolated conduction abnormalities in chronic Chagas' disease. J Am Coll Cardiol 1998; 31(suppl C): 339C.

177. Pazin-Filho A, Almeida-Filho OC, Schmidt A, Simões MV, Marin-Neto JA, Maciel BC. Prognostic implications of minor segmental wall motion abnormalities in patients with Chagas' disease. J Am Coll Cardiol 1998; 31(suppl C): 339C.

178. Bocchi EA, Bellotti G, Mocelin AO, et al. Heart transplantation for chronic Chagas' heart disease. Ann Thorac Surg 1996; 61: 1727-33.

179. Jatene AD, Moreira LF, Stolf NA, et al. Left ventricular function changes after cardiomyoplasty in patients with dilated cardiomyopathy. J Thorac Cardiovasc Surg 1991; 102: 132-8.

180. Moreira LF, Stolf NA, Braile DM, Jatene AD. Dynamic cardio-myoplasty in South America. Ann Thorac Surg 1996; 61: 408-12.

181. Albanesi-Filho FM, Gomes JB. O tromboembolismo em pacientes com lesão apical da cardiopatia chagásica crónica. Rev Port Cardiol 1991; 10: 35-42.

182. Rey RC, Lepera SM, Kohler G, Monteverde DA, Sica RE. Cerebral embolism of cardiac origin. Medicina, Buenos Aires 1992; 52: 206-6.

183. Braga JC, Labrunie A, Villaça F, Nascimento E, Quijada L. Thromboembolism in chronic Chagas' heart disease. São Paulo Med J 1995; 113: 862-6.

184. Simões MV, Bromberg-Marin G, Maciel BC, Marin-Neto JA. Exacerbated 
coronary artery constrictor responses and autonomic dysfunction in vasotonic angina: a comparative study with Chagas' heart disease. J Am Coll Cardiol 1998; 31(suppl C): $340 \mathrm{C}$

185. Ejima FH, Dantas RO, Simões MV, Marin-Neto JA, Meneghelli UG. Intraesophageal balloon distension test in Chagas'disease patients with noncardiac chest pain. Dig Dis Sci 1998; 43: 2567-71

186. Sosa EA, de Paola AAV, Martinelli M, et al. Recomendações do Departamento de Arritmias e Eletrofisiologia Clínica (DAEC) da Sociedade Brasileira de Cardiologia para indicações de implante de marcapasso definitivo, escolha do modo de estimulação e indicações para implante de desfibrilador-cardioversor automático. Arq Bras Cardiol 1995; 64: 579-83.

187. Rassi A, Rassi Jr A, Faria GHDC, et al. História natural do bloqueio atrioventricular total de etiologia chagásica. Arq Bras Cardiol 1992; 59(suppl II): 191.

188. Lorga AM, Garzon SAC, Jacob JLB. Eletrograma do feixe de His na doença de Chagas crônica: localização e evolução do bloqueio atrioventricular. In Davalos AR, ed. - Enfermedad de Chagas. La Paz: Editorial Los Amigos de Libro, 1979: 433-52.

189. Doval HC, Nul DR, Grancelli HD, Perrone SV, Bortman GR, Curiel R Randomized trial of low-dose amiodarone in severe congestive heart failure. Lancet 1994; 344: 493-8.

190. Garguichevich JJ, Ramos JL, Gambarte A, et al. Effect of amiodarone therapy on mortality in patients with left ventricular dysfunction and asymptomatic complex ventricular arrhythmias: Argentine pilot study of sudden death and amiodarone (EPAMSA). Am Heart J 1995; 130: 494-500.

191. Scanavacca MI, Sosa EA, Lee JH, Bellotti G, Pileggi F. Terapêutica empírica com amiodarona em portadores de miocardiopatia chagásica crônica e taquicardia ventricular sustentada. Arq Bras Cardiol 1990; 54: 367-71.

192. Gondin FAA, de Paola AAV, Silva RMFL, Metha N, Martinez Filho EE Eficácia e tolerância ao sotalol em pacientes com taquiarritmias ventriculares sustentadas. Arq Bras Cardiol 1994; 62: 64

193. The Antiarrhythmics Versus Implantable Defibrillators (AVID) Investigators - A comparison of antiarrhythmic drug therapy with implantable defibrillators in patients resuscitated from near-fatal sustained ventricular arrhythmias. N Engl J Med 1997; 337: 1576-83

194. Magalhães L, Sosa E, Barbero-Marcial M, et al. Resultados da Crioablação Endomiocárdica Interpapilar no Tratamento da Taquicardia Ventricular Chagásica. Arq Bras Cardiol 1994; 63(supl I): 66.

195. Távora MZP, Mehta N, Silva RMFL, Gondin FAA, Hara VM, de Paola AAV. Clinical impact and mechanisms of radiofrequency catheter ablation of sustained ventricular tachycardia in patients with Chagas Disease. J Am Coll Cardiol 1998; 31(suppl C): 415C

196. Sanchez OD, Sosa E, Scanavacca M, et al. Ablação endocárdica da taquicardia ventricular sustentada em pacientes chagásicos: resultados a longo prazo. Arq Bras Cardiol 1997; 69(supl I): 107

197. Sosa EA, Scalabrini A, Rati M. Successful catheter ablation of the source of recurrent ventricular tachycardia in chronic chagasic heart disease. J Electrophysiol 1987; 1: 58-61.

198. de Paola AAV, Melo WDS, T·vora MZP, Martinez EE. Angiographic and electrophysiological substrates for ventricular tachycardia mapping through the coronary veins. Heart 1998; 79: 59-63.

199. Sosa E, Scanavacca M, d'Avila A, et al. Endocardial and epicardial ablation guided by nonsurgical transthoracic epicardial mapping to treat recurrent ventricular tachycardia. J Cardiovasc Electrophysiol 1998; 9: 229-39.

200. Marin-Neto JA, Simões MV, Sarabanda AVL. Doença cardíaca no indivíduo assintomático com moléstia de Chagas. Rev Soc Cardiol Est SP 1997; 7: 726-34. 